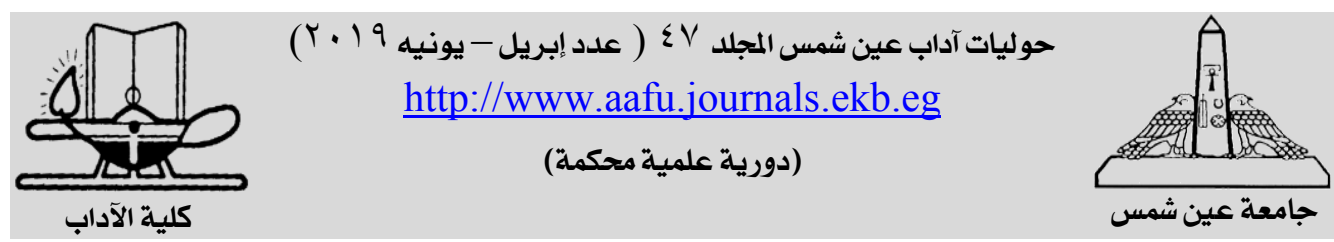

\title{
اتجاهات الامهات نحو شراء الالعاب الاكترونية لاطفالهن
}

شيماء حارث محمد

* الأستاذ المساعد بجامعة بغداد/ كلية التربية للبنات/ قسم رياض الاطفال

يهدف البحث الى التعرف على اتجاهات الامهات نحو شر اء الالعاب الالكترونية

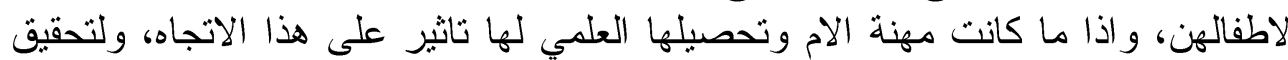

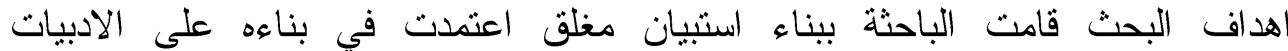

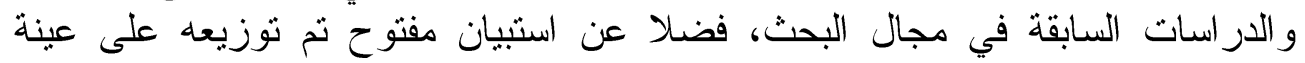

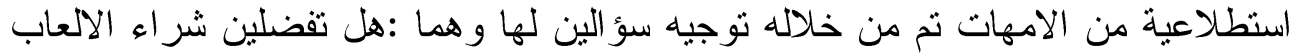

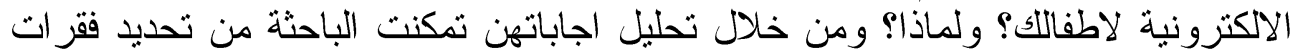

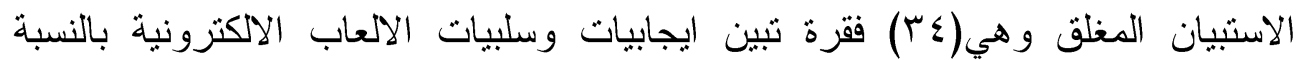

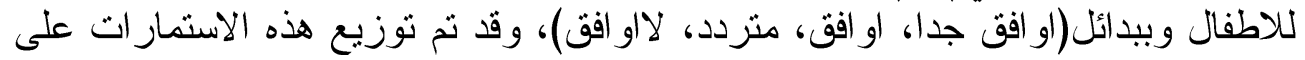

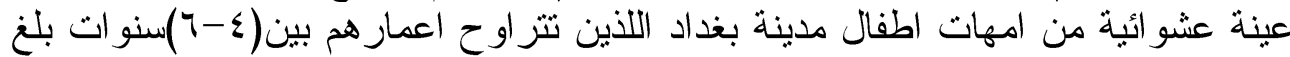

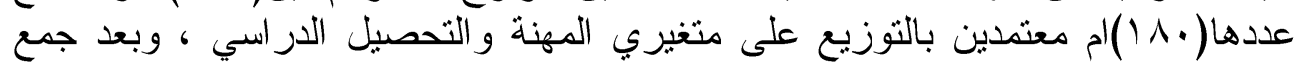

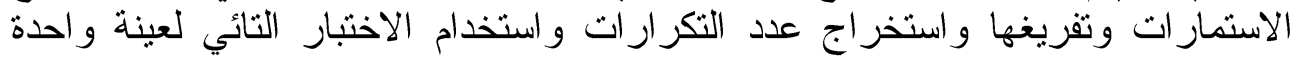

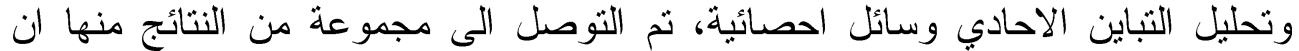

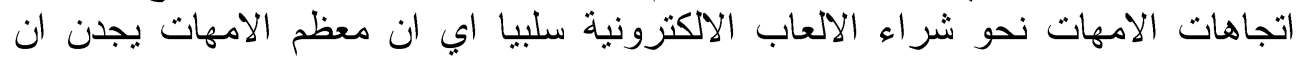

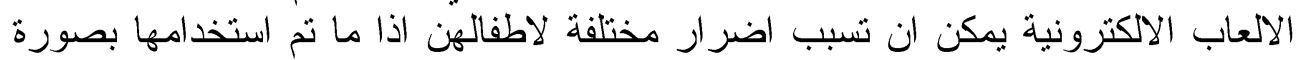

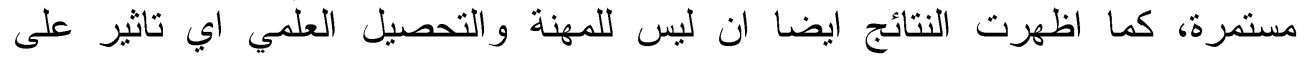

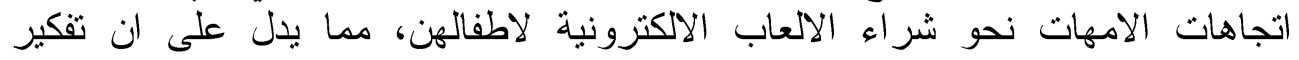

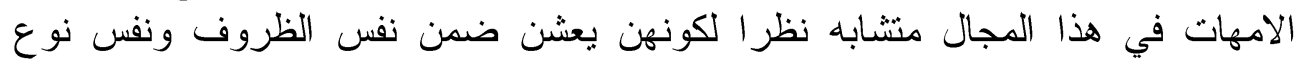
وبناءا على نتائج البحث تم تقديم عدد من التوصيات المتعلقة بضرورة الاهنمام

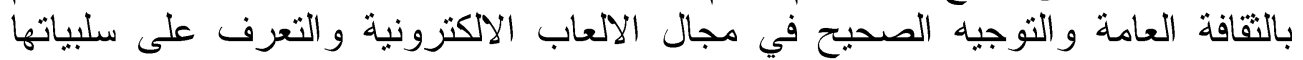
و ايجابياتها ليكون اتجاه اولياء الامور صحيحا و و اعيا عند شر اءهم للالعاب الالكثرونية لابناءهم. 


\section{الفصل الاول}

لقد اكدت البحوث الحديثة ان اللعب هو مدخل وظيفي لعالم الطفولة، ووسيط مشكلة البحث

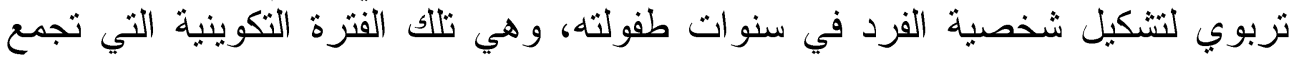

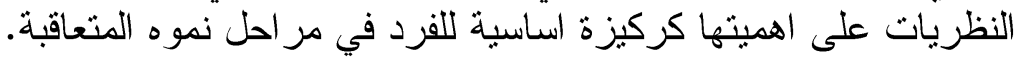

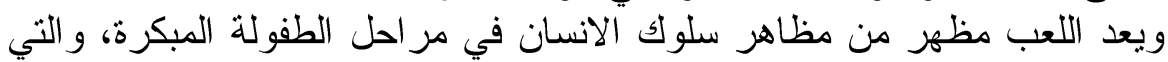

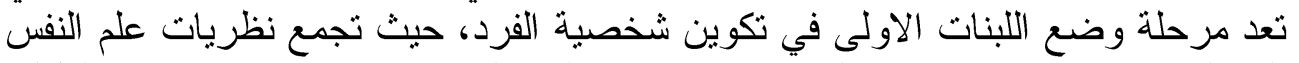

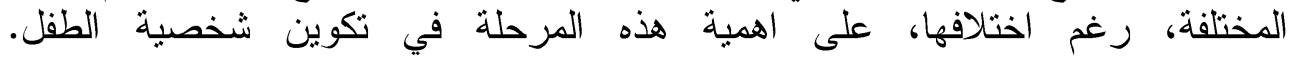

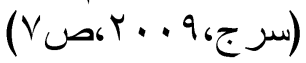

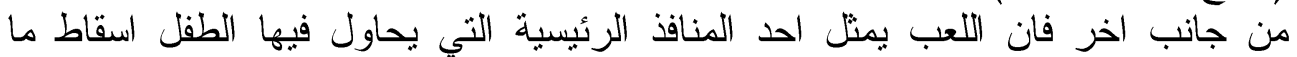

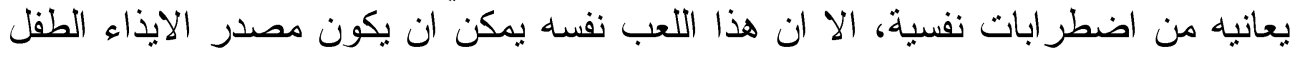

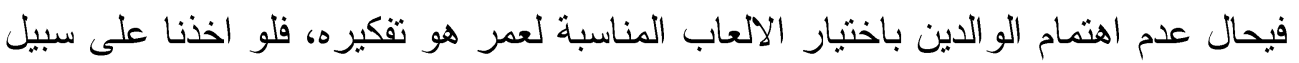

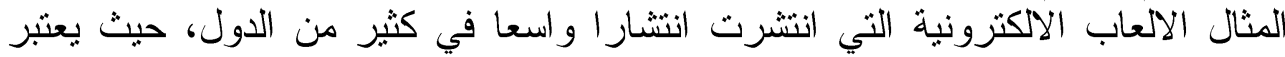

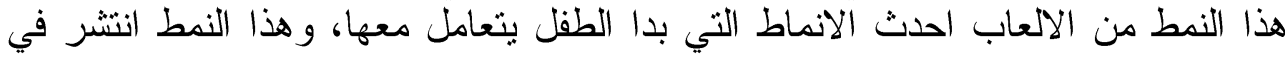

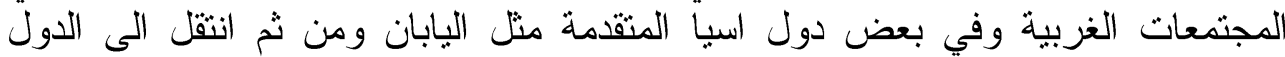

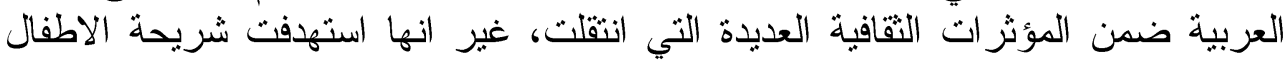

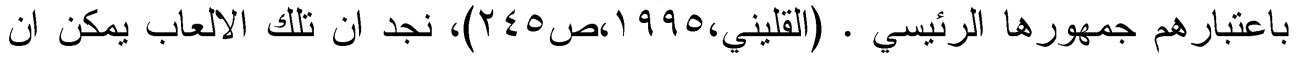

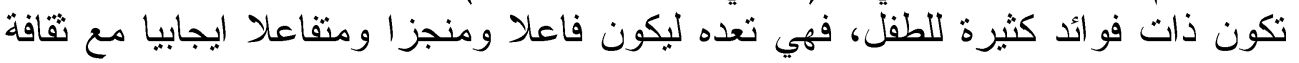

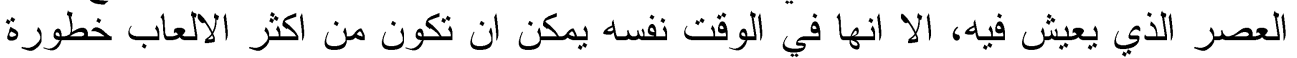
على صحته الى درجة جعل الكثير من الباحثين يقلقون من تلك الته التاثير ات التهن السلبية

(Gunter, 1991, p /7).

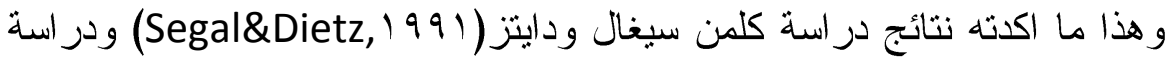

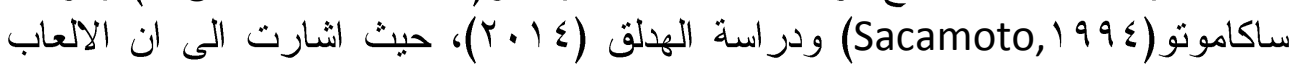
الالكترونية يمكن ان تكون ذات اضرار صحية وسلوكية واخلافية على الاطفال، فهي

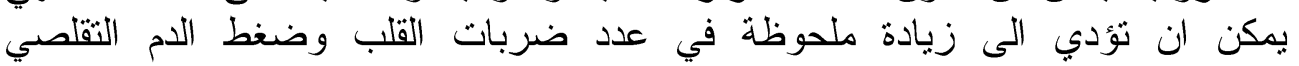

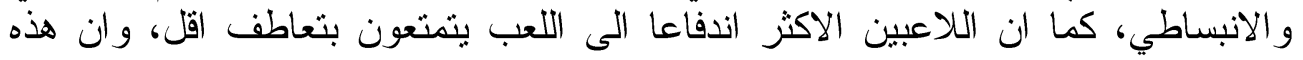

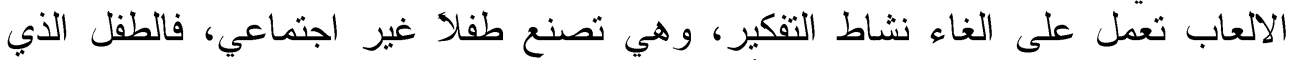

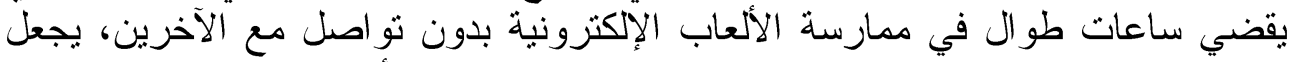

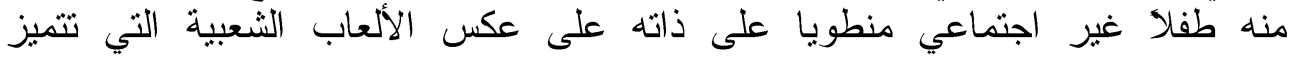

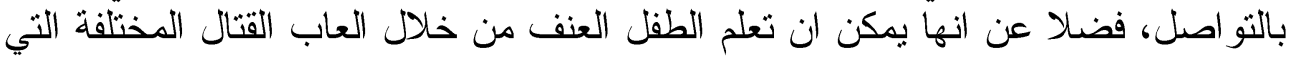

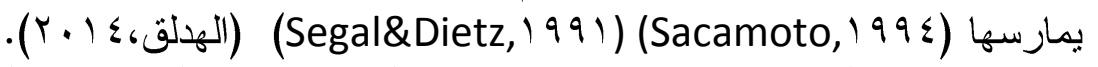

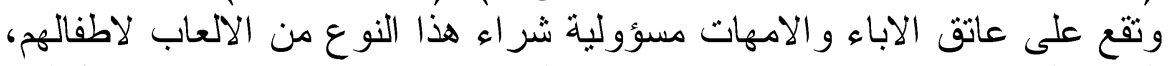

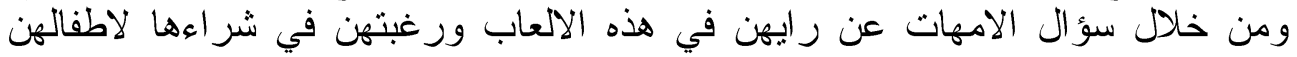

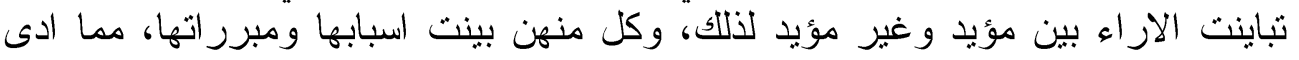

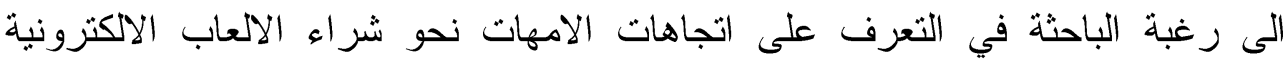

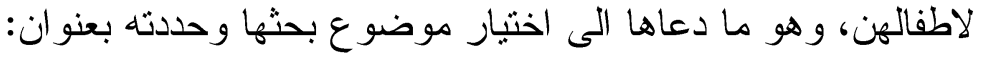
(اتجاهات الامهات نحو شر اء الاء الألعاب الالكترونية لاطفالهن)

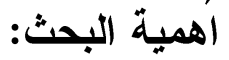

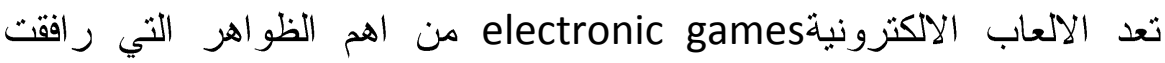
ظهور الحاسوب وتطوره، وهي في المفهوم المعلوماتي برمجيا تتحاكي و اقعا حقيقيا او الفي 


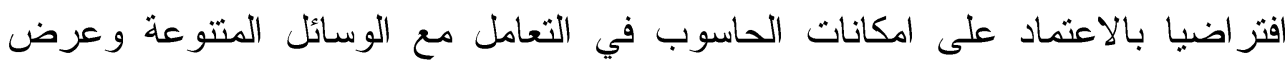

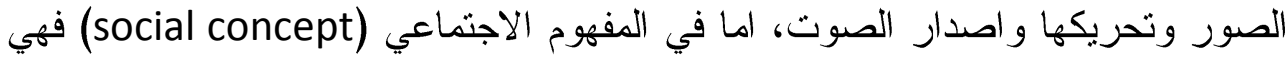

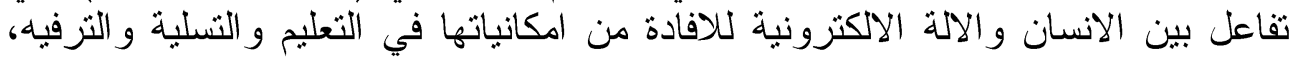

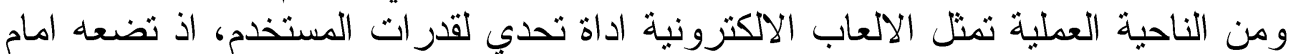

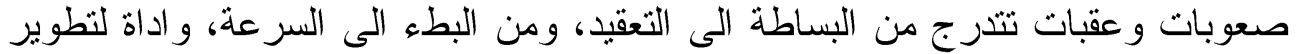

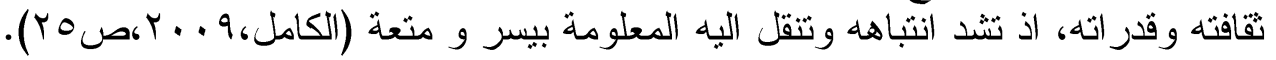

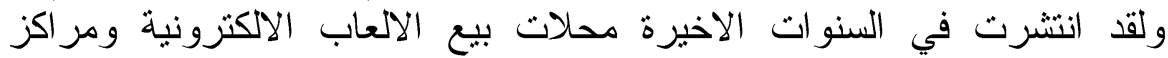

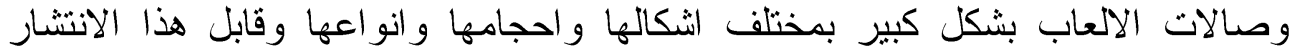

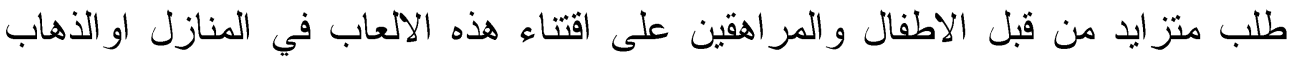

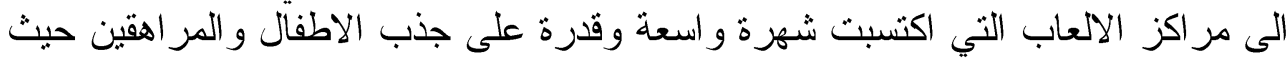

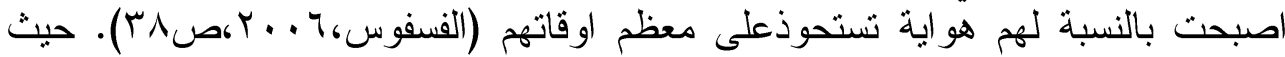

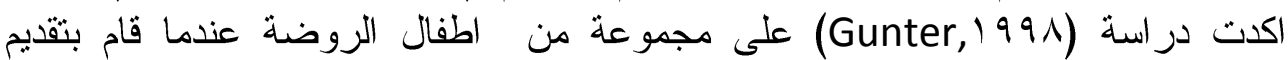

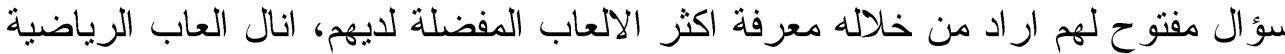
العنيفة قد حصلت على المرتبة الاولى ومن ثم جاءت الالعاب الالكترونية العنيفة بالمرتبة العابة الثانية ( Gunter, $199 \wedge, p \vee$ (

وفي ظل غياب اجزة الرقابة الرسمية على محلات بيع الالعاب الالكثرونية

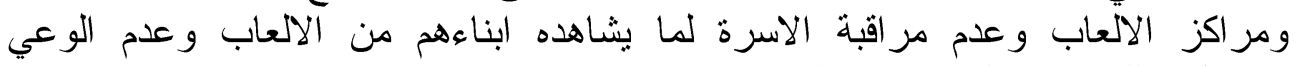

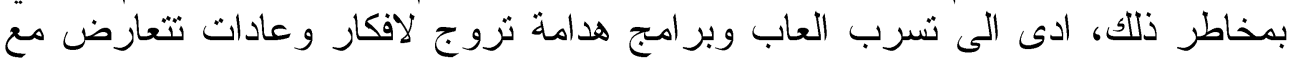

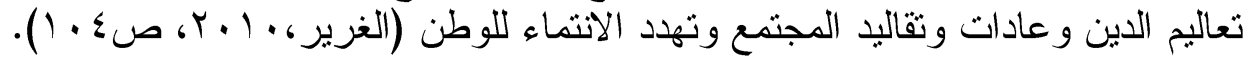

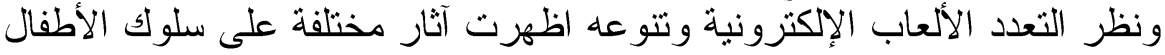

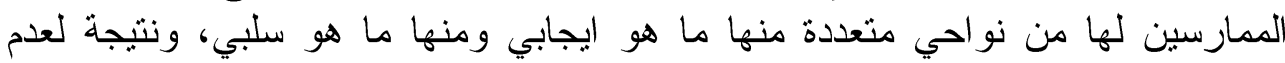

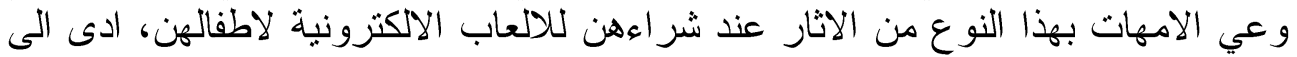

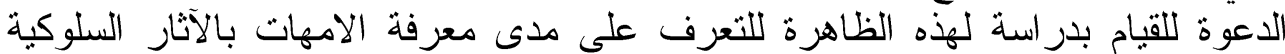

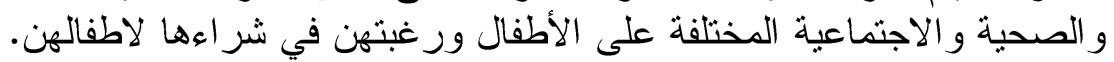
ولقد دعت عزة كريم إلى إجراء دراسات وبحوث حول مخاطر الألعاب الإلكترونية

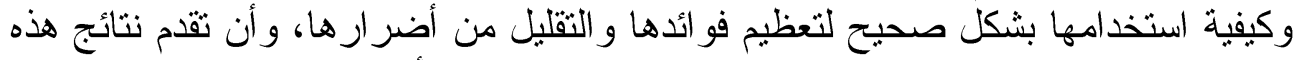

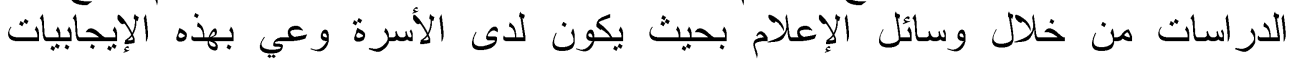

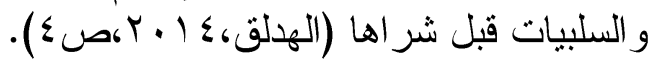

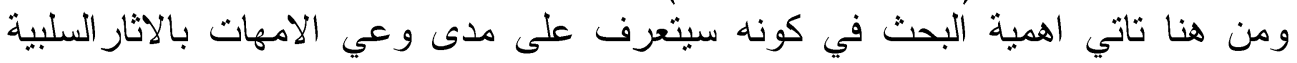

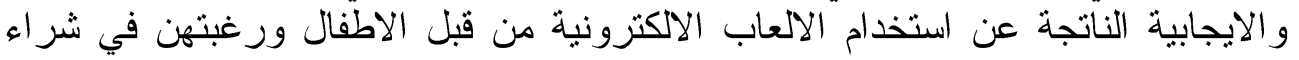

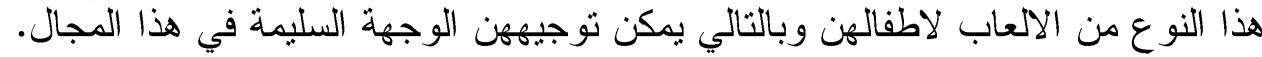

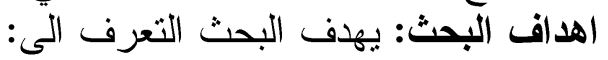

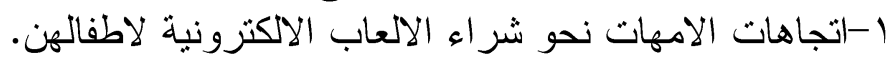

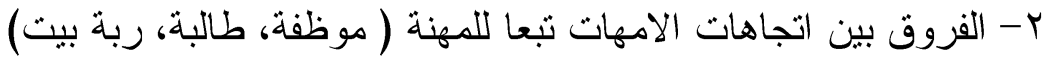

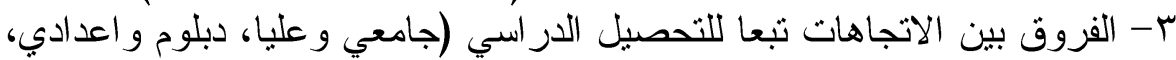
منوسطة و ابتدائي) من خلال التحقق من الفرضيات الصفرية الاتية:

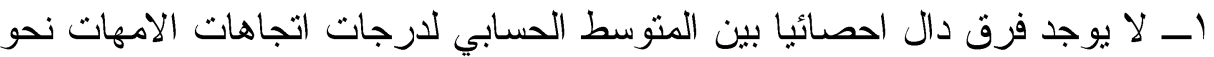
شر اء الالعاب الالكترونية والمتوسط الفرضي للمقياس عند مستوى دلالة (0. . •). 
r- لاتوجد فروق دالة احصائيا بين اتجاهات الامهات نحو شر اء الالعاب الالكترونية تبعا

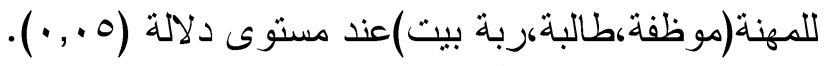

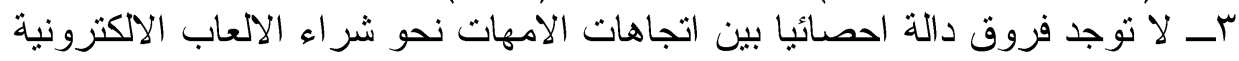

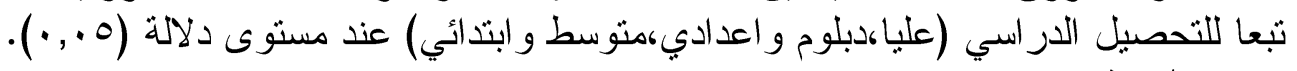
حدود البحث: البهئ 1 الحــالحدود المكانبة: بغداد/العر اق.

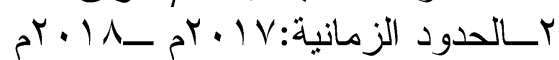

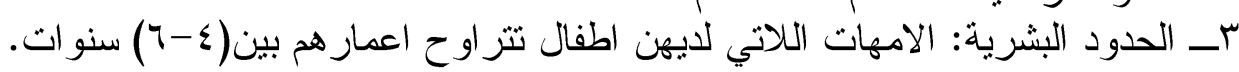

Attitude الالاتجاه

لا يوجد تعريف واحد مقتع يعترف به جميع المشتخلين في الميدان، إلا أن التعريف

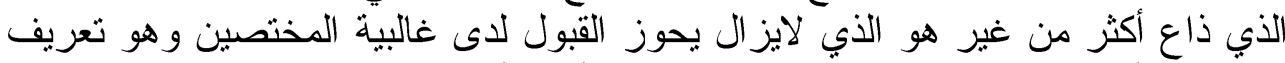

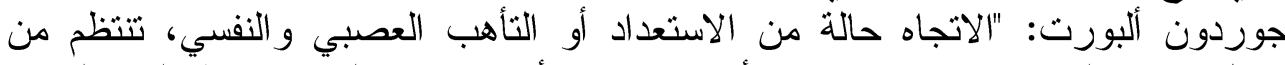

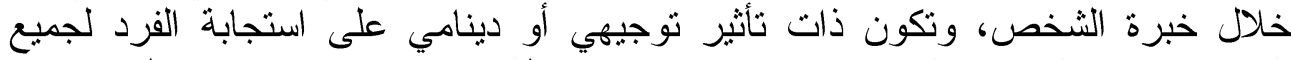

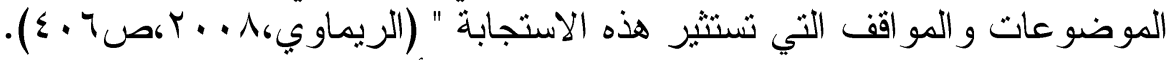

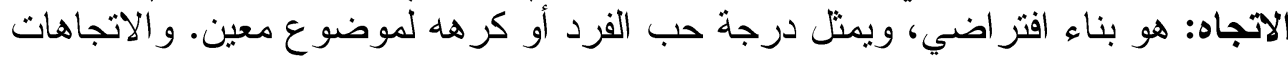

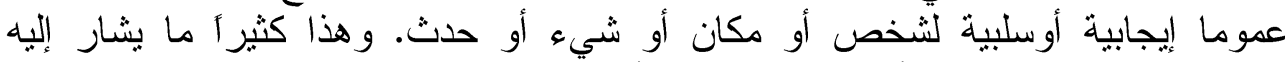

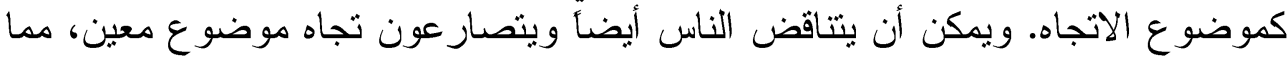

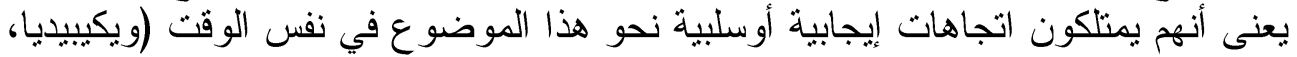

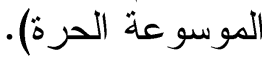

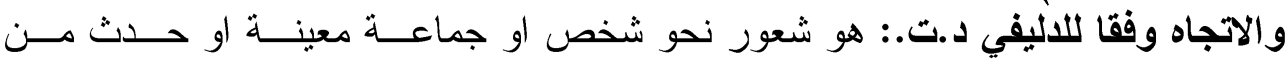

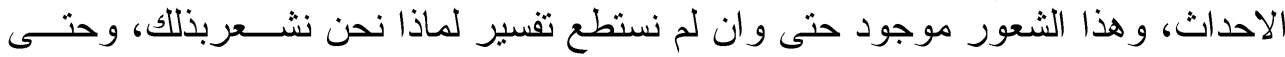

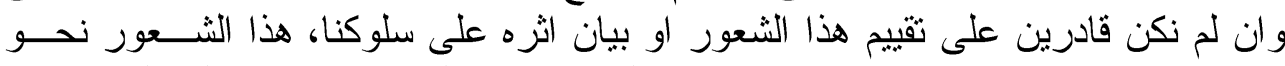

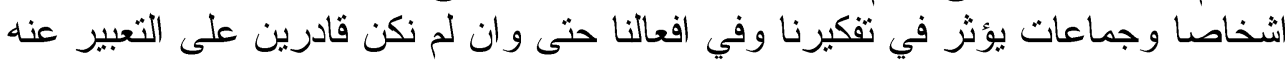

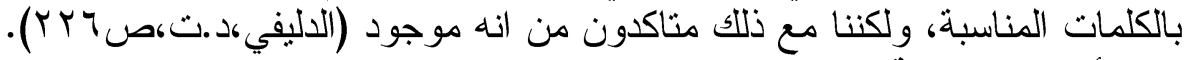

rالألعابالإكترونية:

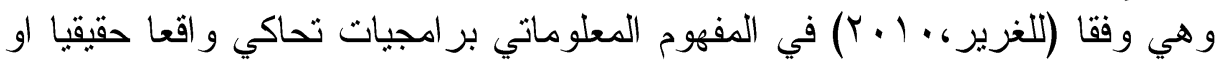

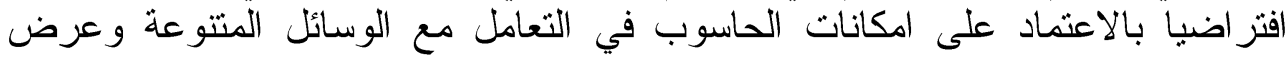

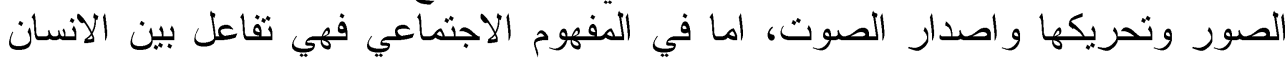

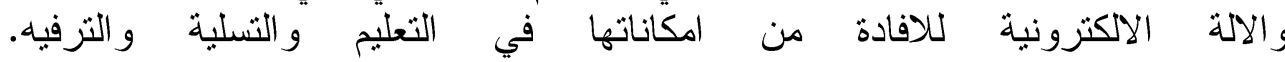

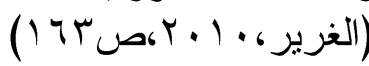

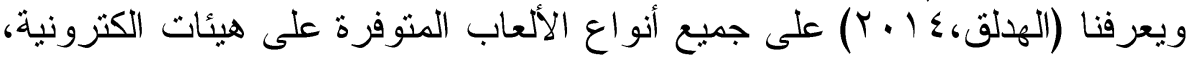

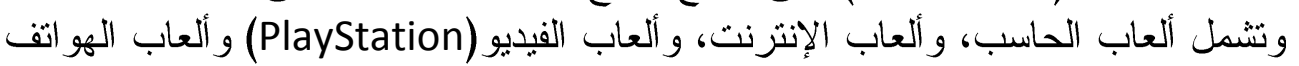

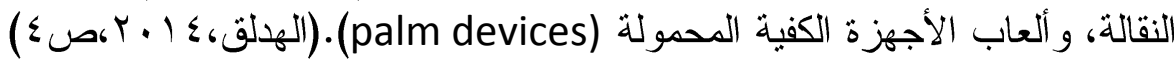



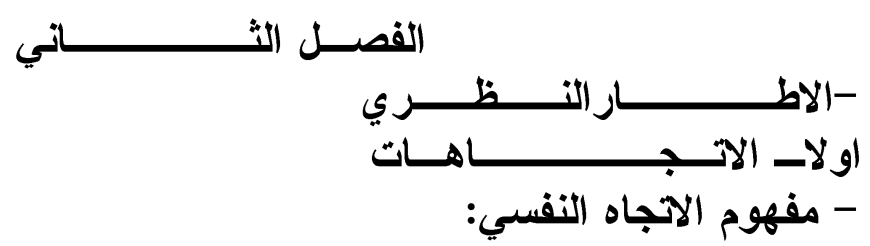

تمثل الاتجاهات جزءا من الموره المورث الثقافي لكل مجتمع من المجتمعات، وهذا

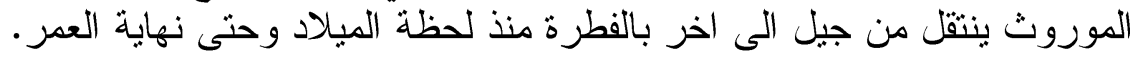

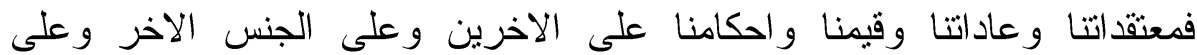

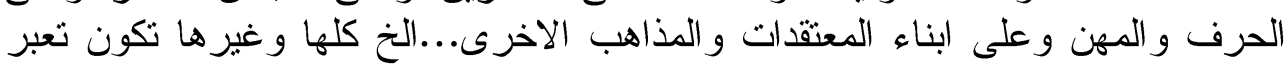

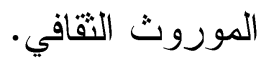

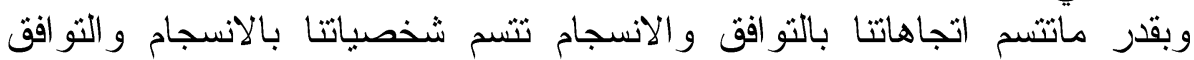

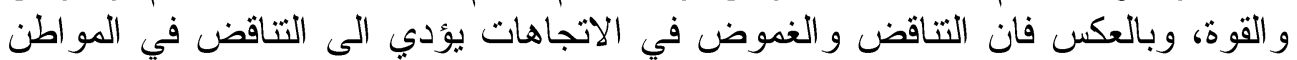

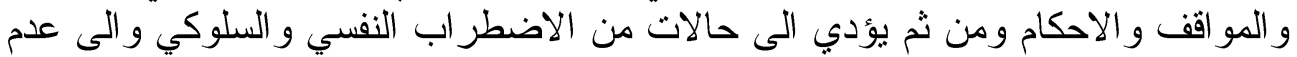
الوضوح فيما نريد او نون ونوي. ومن ذلك بتضح ان فئن فئا لشخصية الانسان بعتمد بالدرجة الاولى على فهمن

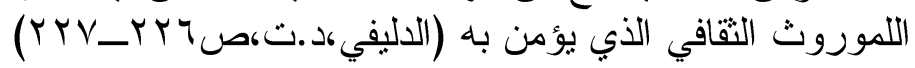

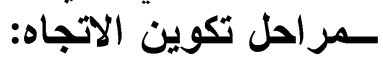

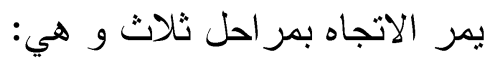

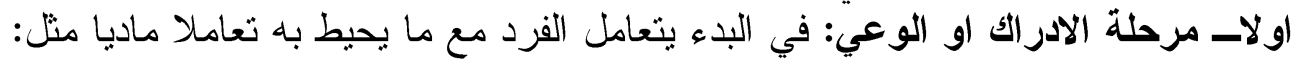

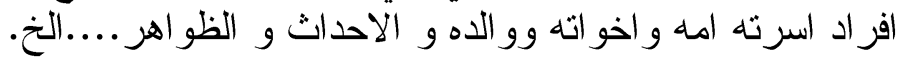

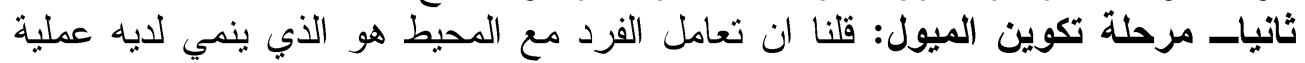

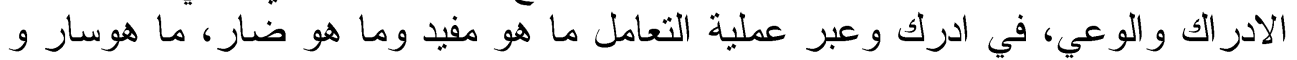

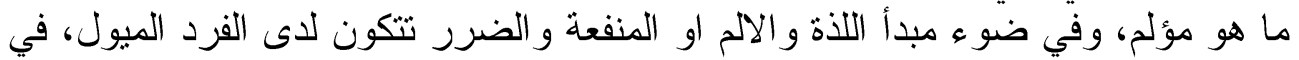

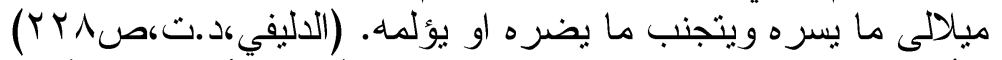

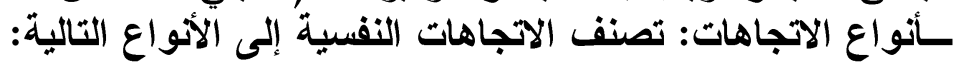

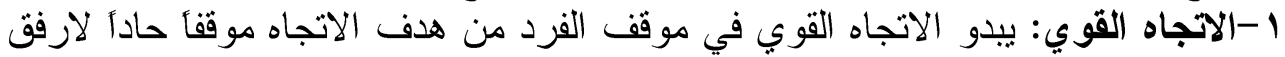

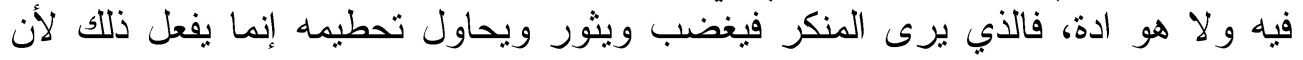

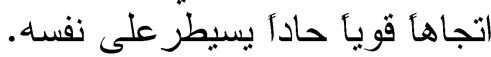

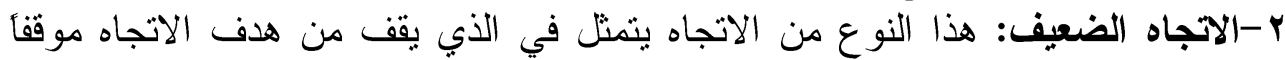

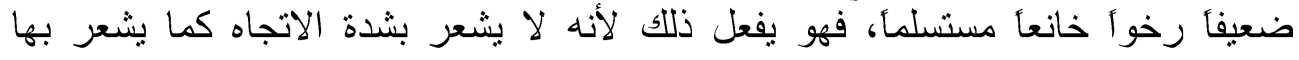

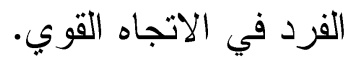

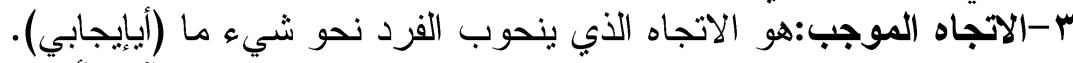

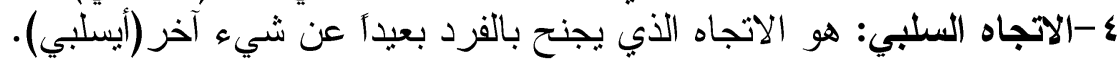

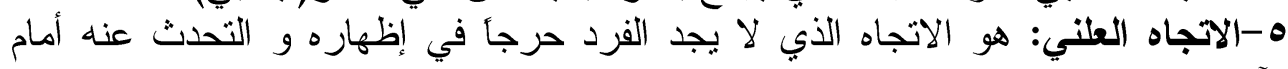
צ-الاتجاه السري: هو الاتجاه الذي يحاول الفرد إخفائه عن الآخرين ويحتفظ به في

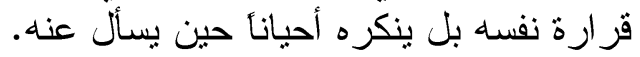

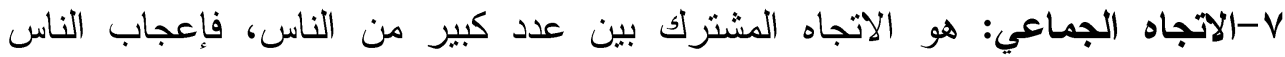
بالأبطال اتجاه جماعي. 
^-الاتجاه الفردي: هو الاتجاه الذي يميز فردأ عن آخر، فإعجاب الإنسان بصديق له

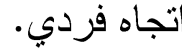

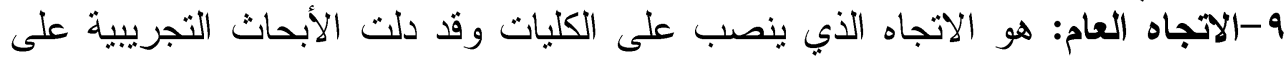

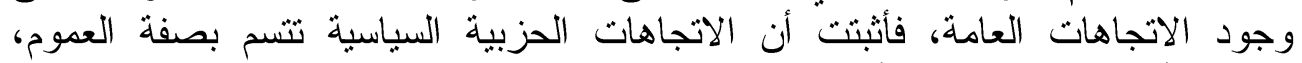

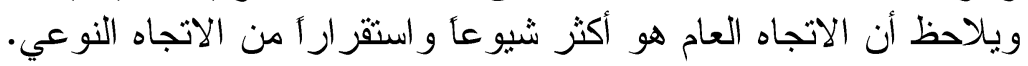

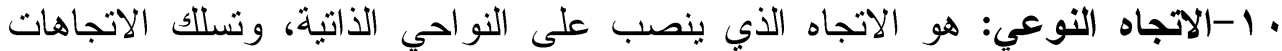

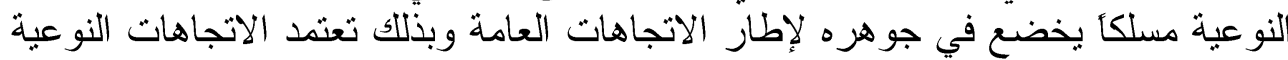

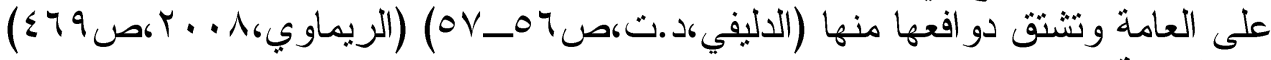

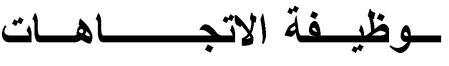
للاتجاهات وظائف مهمة جدا نذكر منها مايلي: التهات

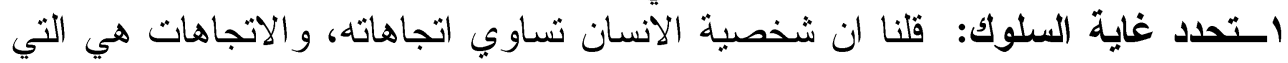

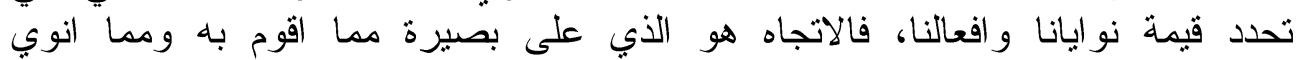
ممارسته.

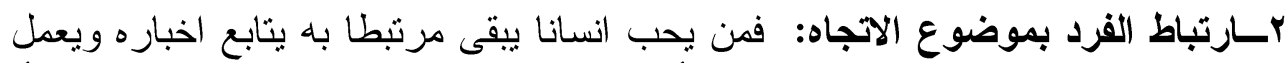

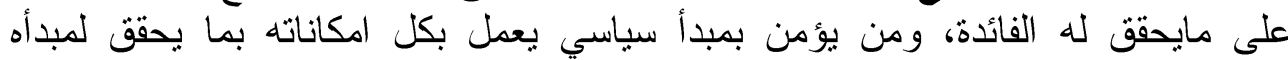

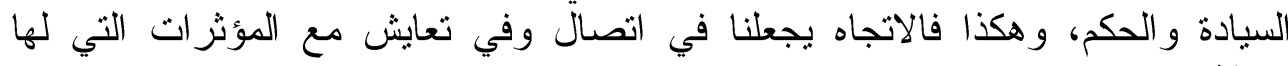

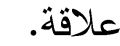
rاسـالاستمرارية في العمل: الاتجاهات القوية تدفع اصحابها الى العمل الدائم و الى التقكير

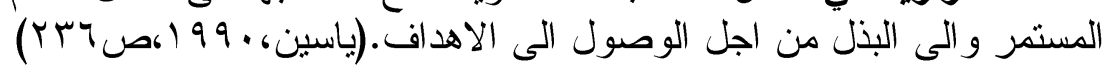
لخصائص الاتجاهات من اهم الخصائص التي نشتمل عليها الاتجاهات نذكر منها ما بلي:

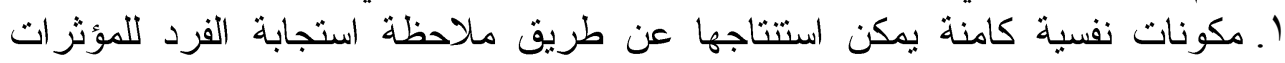

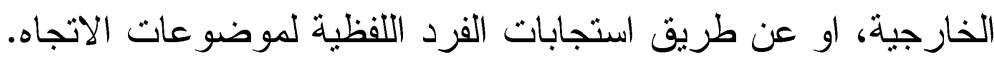

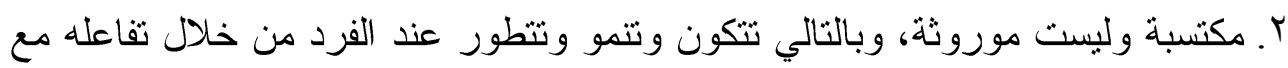

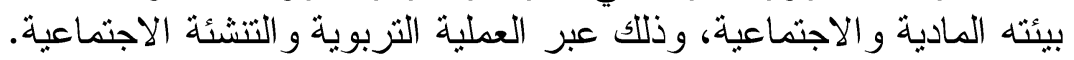

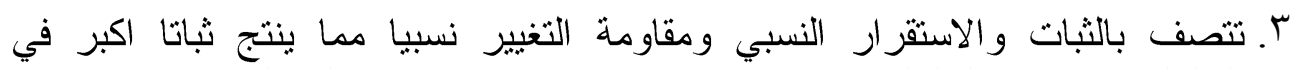

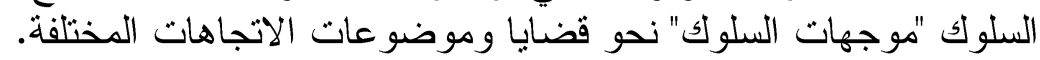

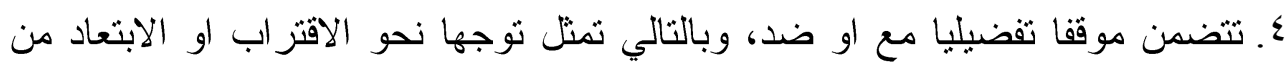

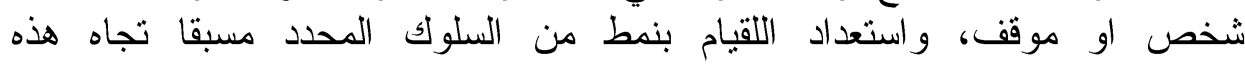

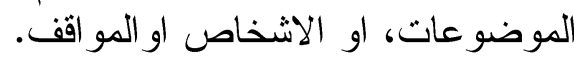

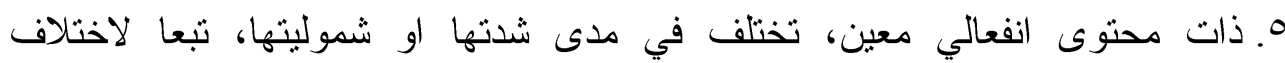

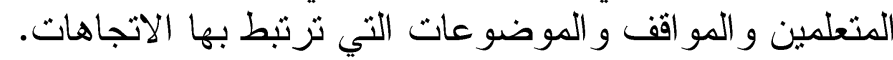

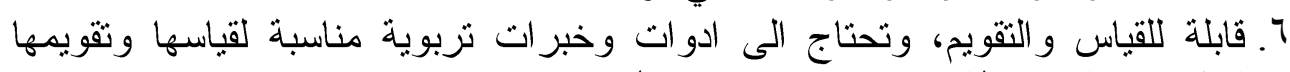

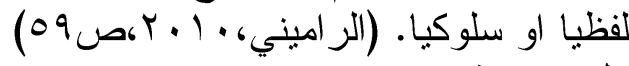

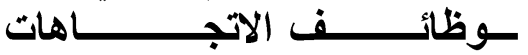
ا ـ تضفي على ادر الك الفرد ونشاطه اليومي معنى ودلالة ومغزى.

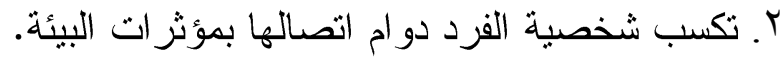
r. تساعد الفرد في محاولته لتحقيق الهدافه.

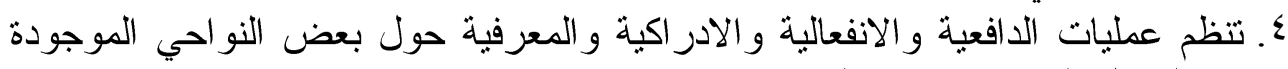
في المجال الذي يعيش فيه الفرد. 
ه. توجيه استجابات الفرد نحو الاشخاص و الاشياء و الموضو عات بطريقة شبه ثابتة.

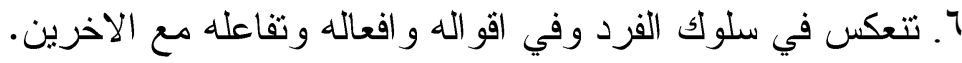

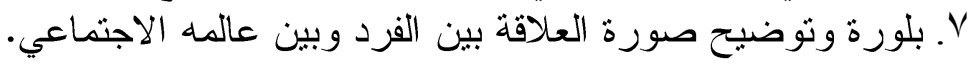

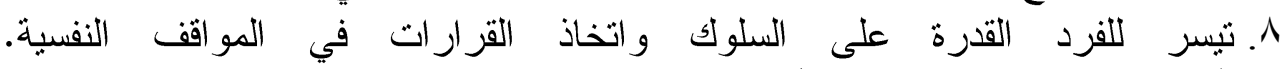

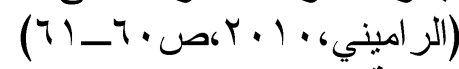

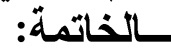

خلاصة القول أن الاتجاهات النفسية تمثل نظامأ منطورأ للمعتقدات و الميول

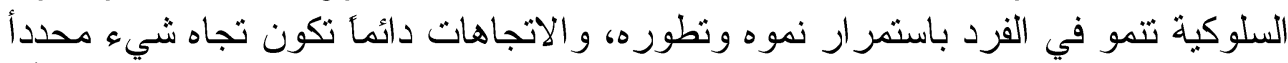

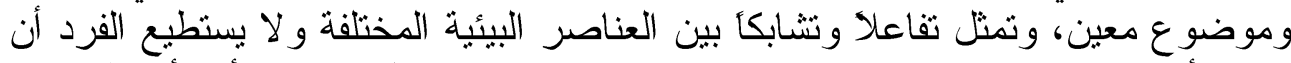

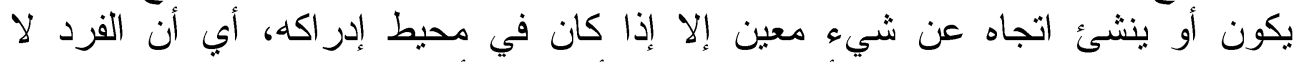

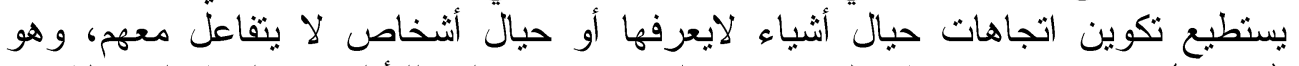

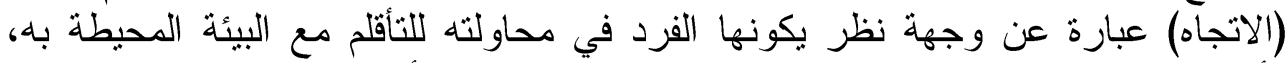

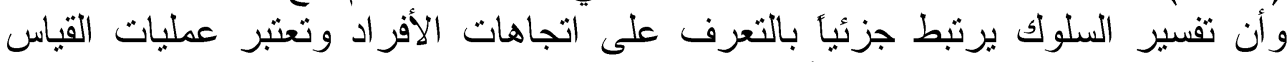

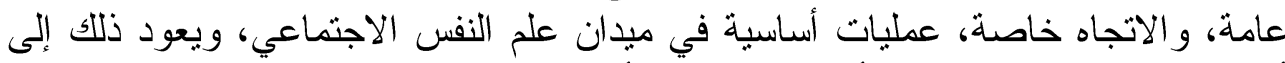

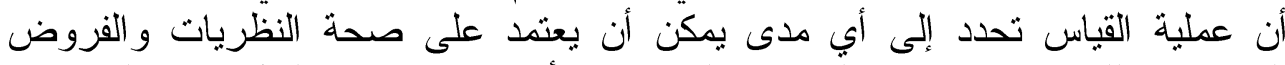

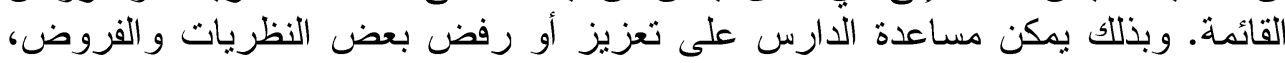

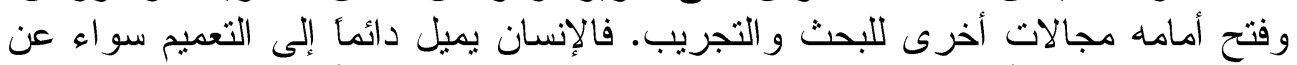

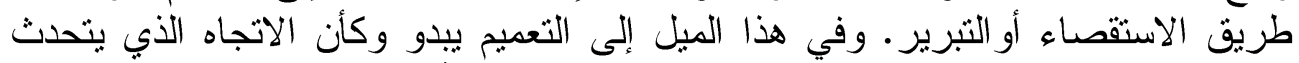

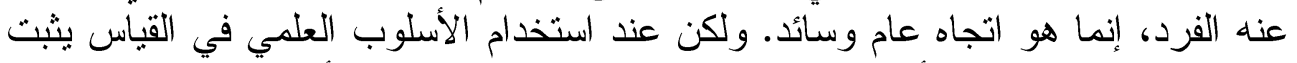

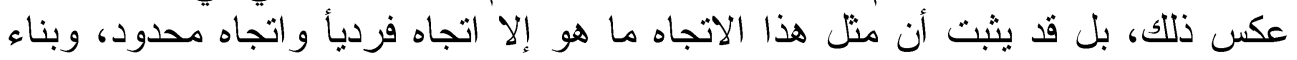

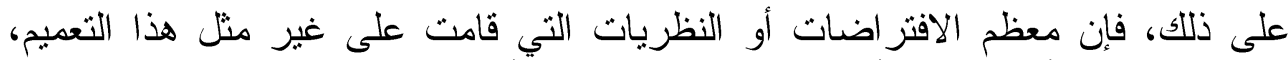

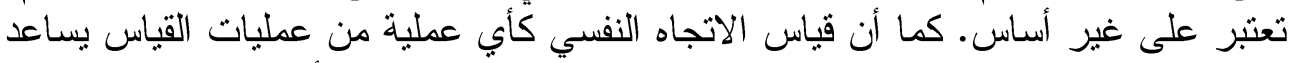

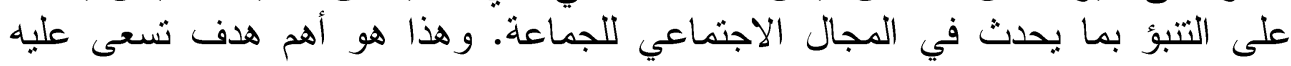

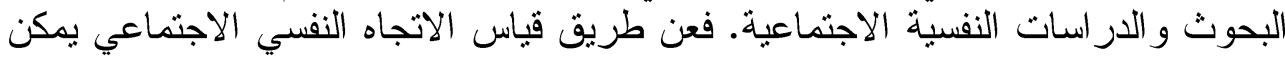

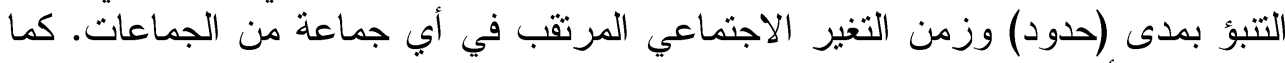

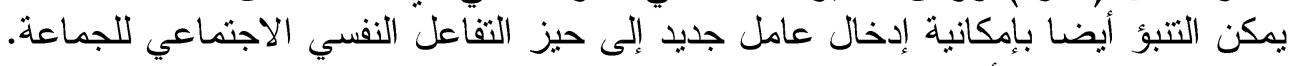

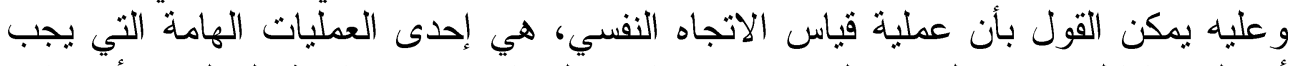

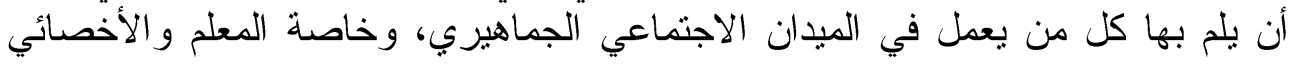

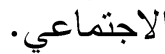

ثانيا - الاجئماب الاكترونية

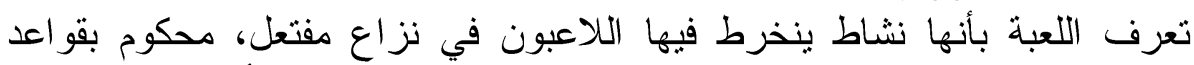
معينة، بشكل يؤدي إلى نتائج قابلة للقياس الكمي. ويطلق على فئل لعبة ما بأنها إلكترونية في

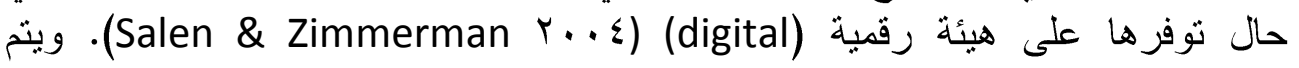

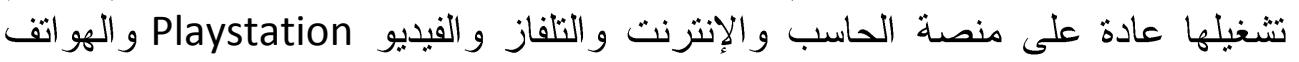

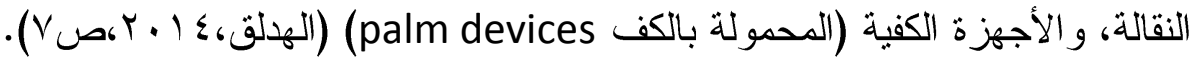

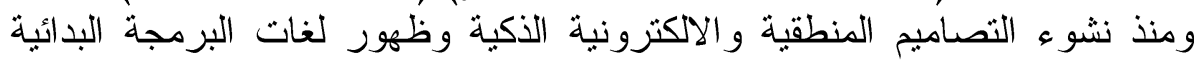

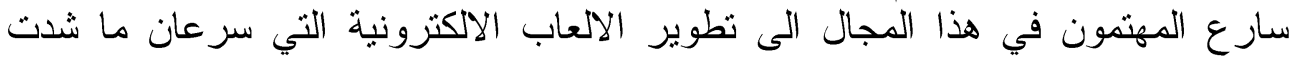

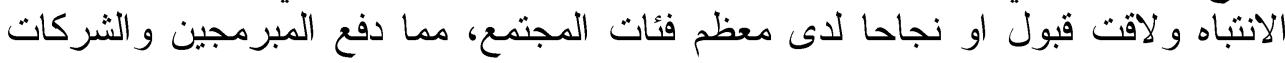


الى بذل كثير من الجها في تطوير كل من الاجزة و البرامج الخاصة بها حتى باتت هذه

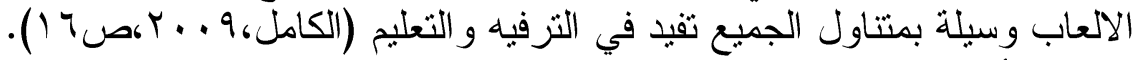

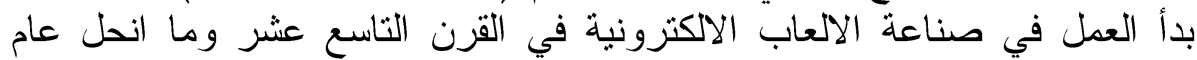

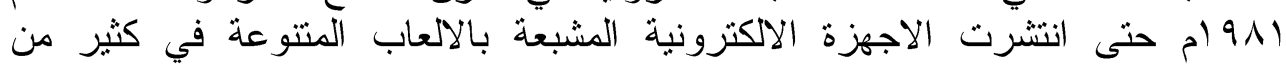

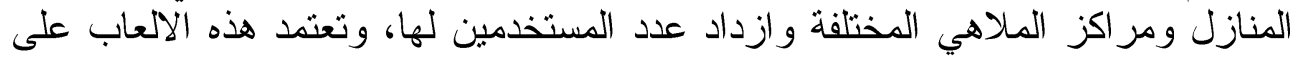

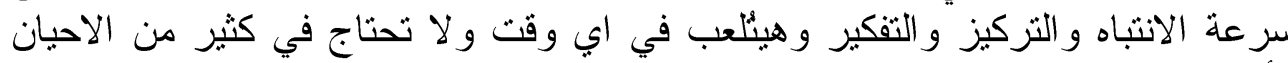

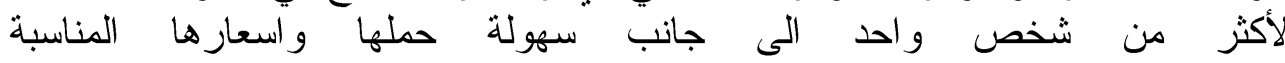

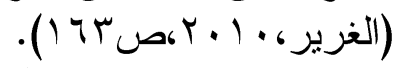
ويمكن تصنيف الالعاب الالكترونية من حيث الهذف منها وشريحة مستثمريها الى

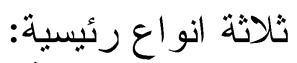
اولا:العاب المتعة والآثارة

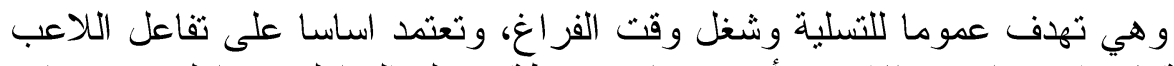

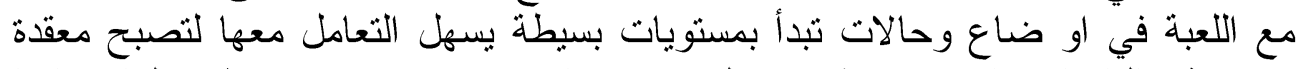

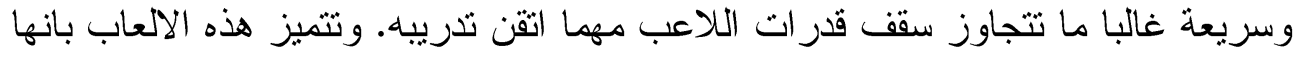

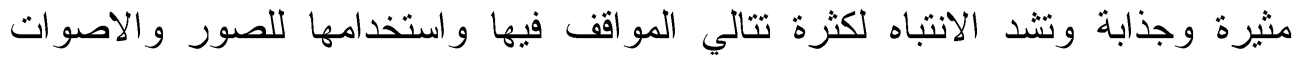

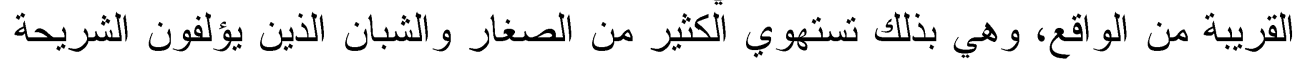

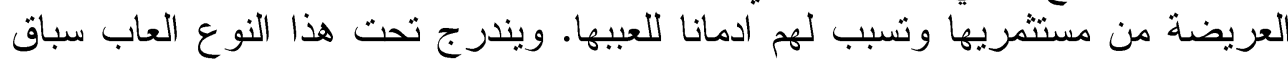

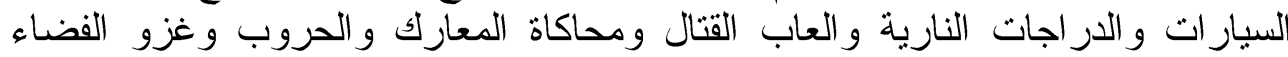

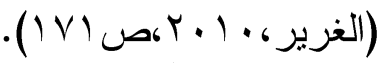

ثانيا:العاب الذكاء

تعتمد هذه الالعاب على المحاكمات المنطقية في اتخاذ القرار، وتتطلب اعمال الفكر للتعامل معها، ولعل الثنطر نج من الشهر الآلعاب في هذا فئ المجال. ثالثا:الالعاب التربوية والتعليمية التطية

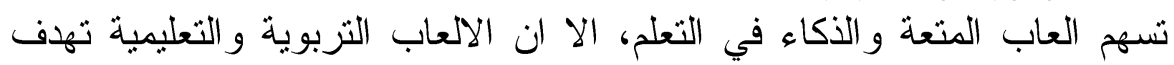

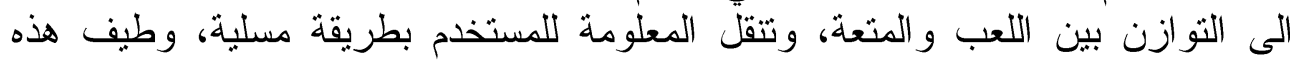

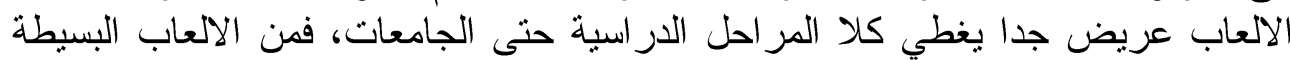

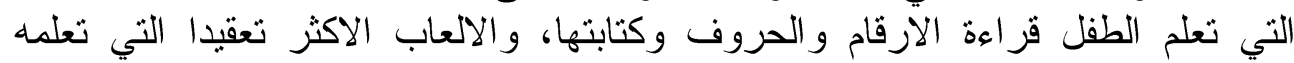

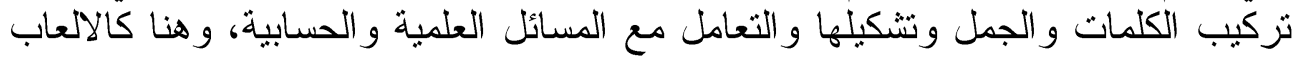

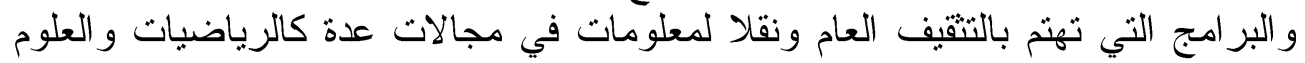

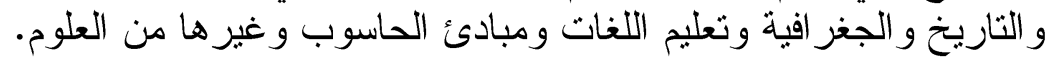

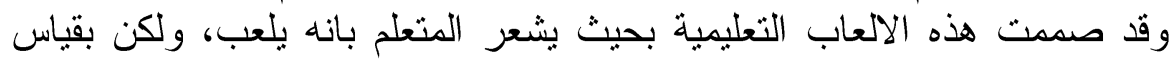

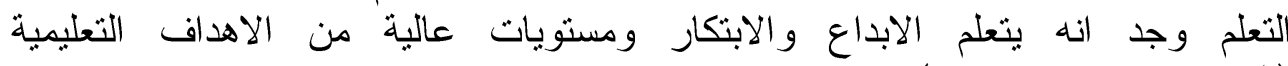

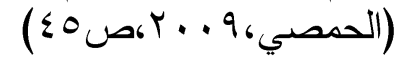

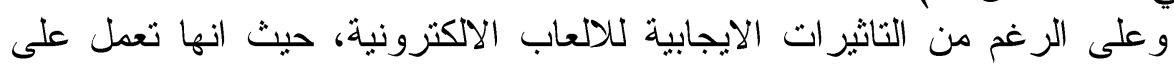

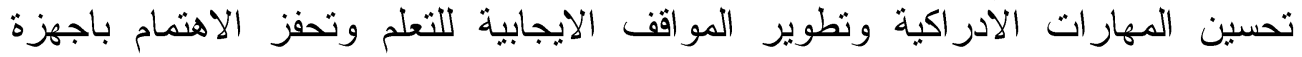

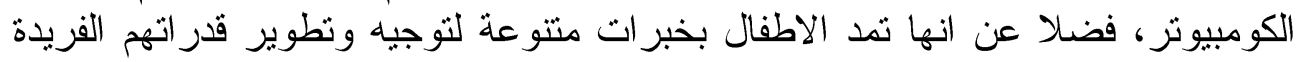

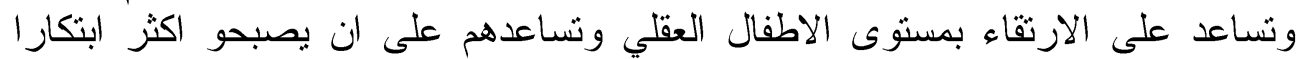

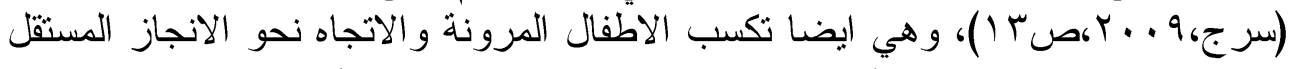

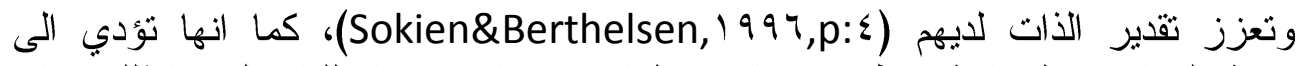
تتمية المهارات الحركية وتظوير مهارات التفكير وزيادة الانتباه للفاصيل، وكذلك زيادة 


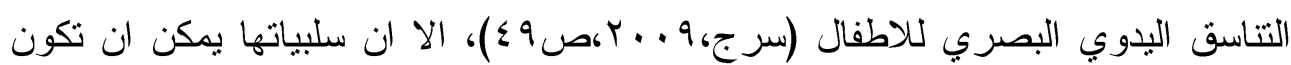

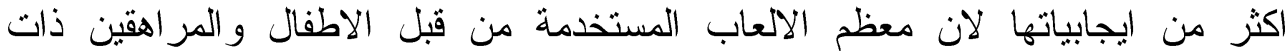

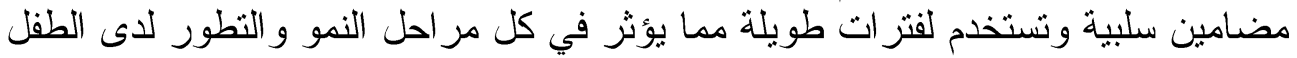

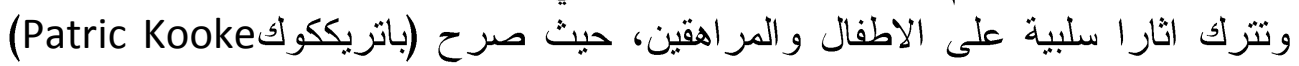

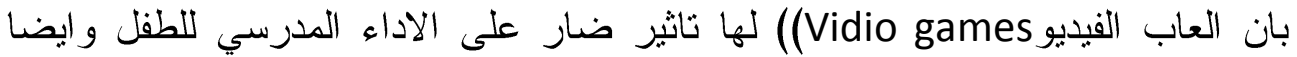

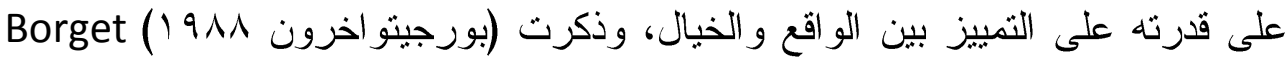

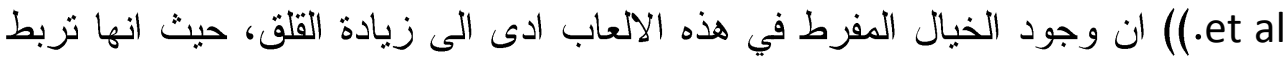

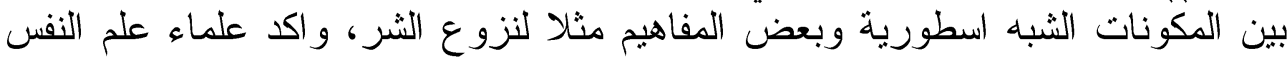

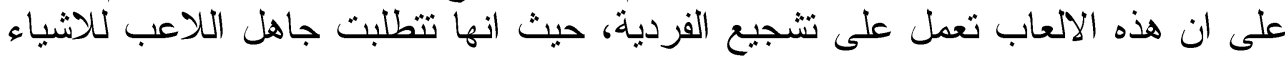

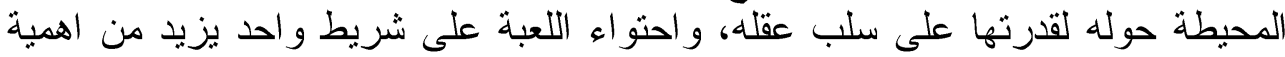

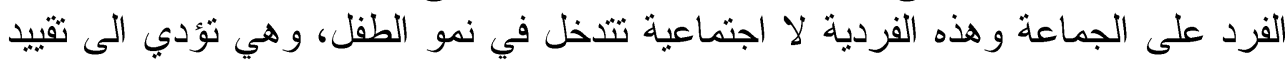

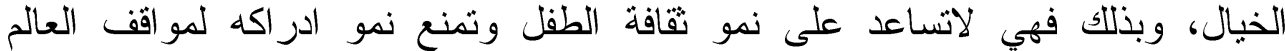

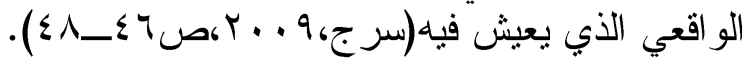

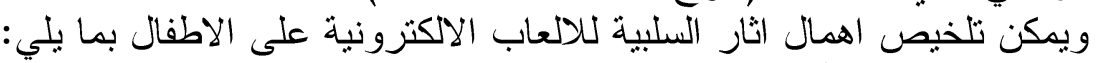

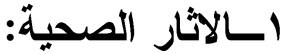

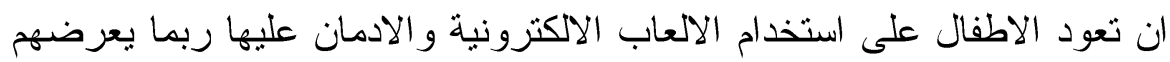

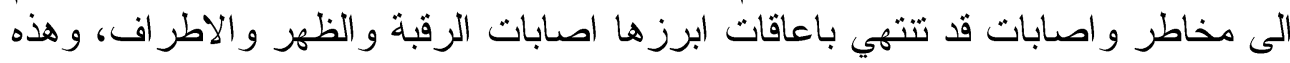

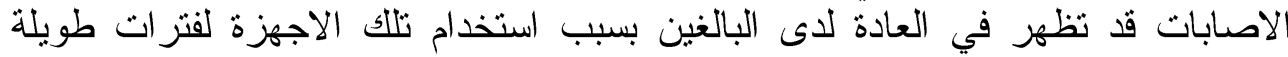

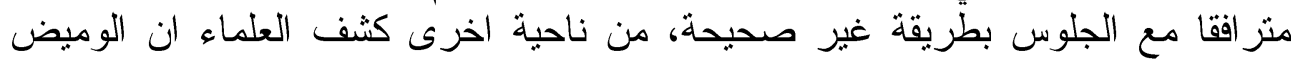

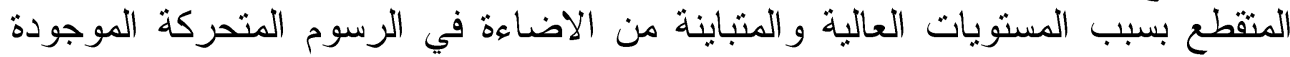

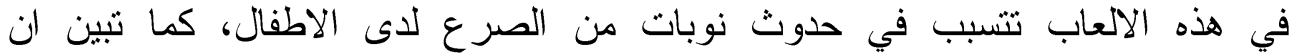

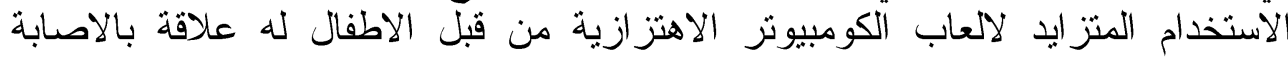

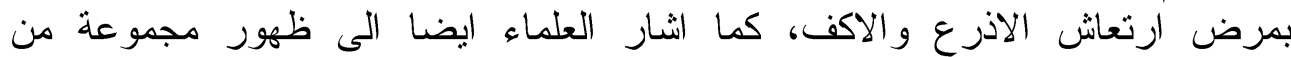

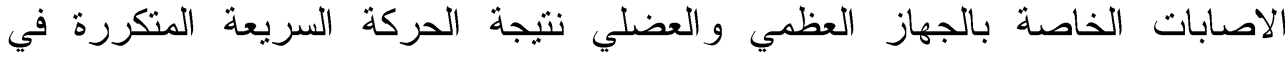

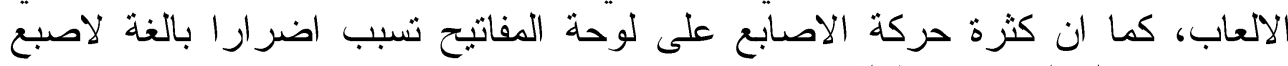

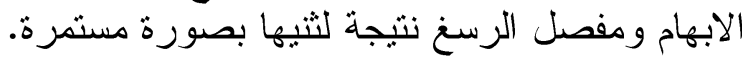
كما تشير الابحاث العلمية الى ان حركة العينين تكون سريعة جدا اثناء ممارسة

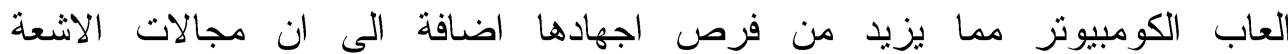

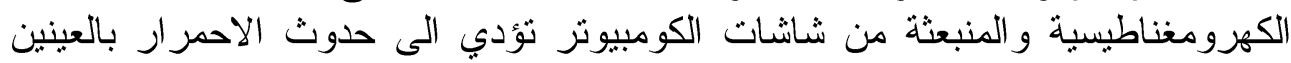

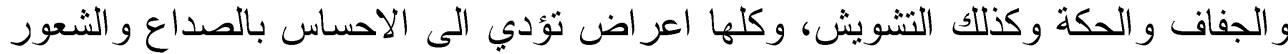
بالاجهاد البنني و احيانا الشعور بالقلق و الاكتئاب.

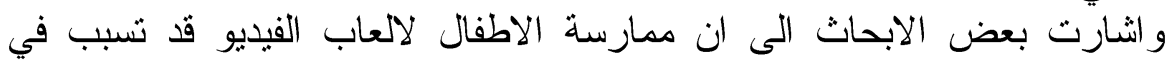

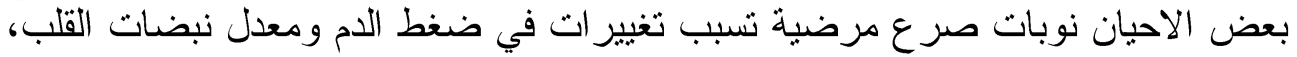
وقد تكون هذه الاعر اض البدان البدنية عرضية اومحدودة لدى عدد قليل من الاطفال.

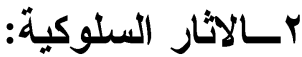

\section{أستربية الاطفال والمر اهقين على العنف والعدوان:}

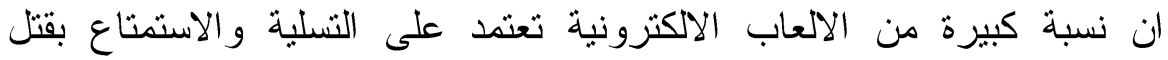

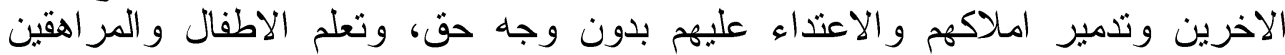

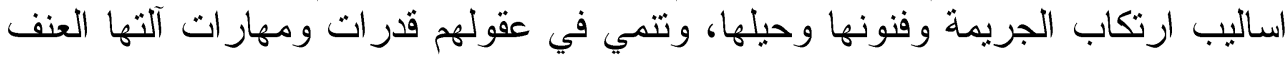


و العدوان ونتيجتها الجريمة، وهذه القدرات مكتسبة من خلال الاعتياد على ممارسة تلك

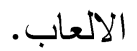

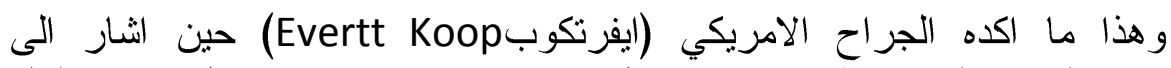

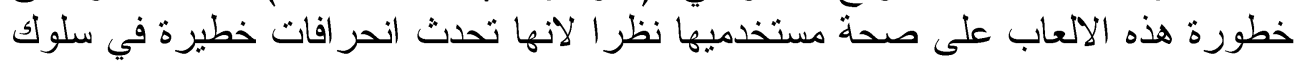

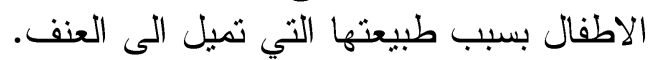

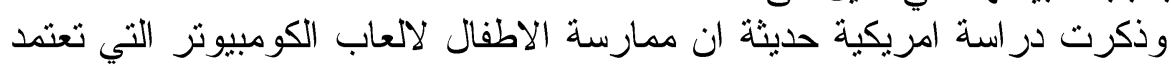

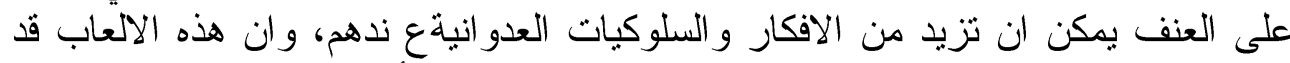

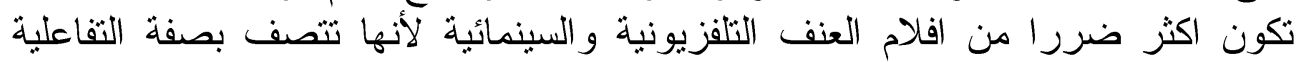
بينها وبين الطفل وتتطلب من الطفل ان يتقمص الثخصية العدو انية ليلعبها ويمارسها. بـاشاعة الفاحشة و الجنس بين المر اهقين و الاطفال:

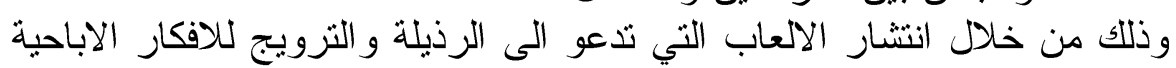

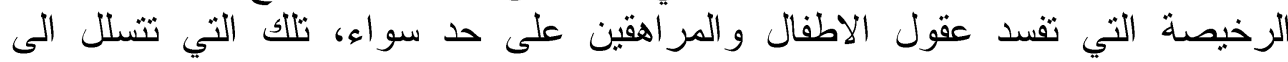

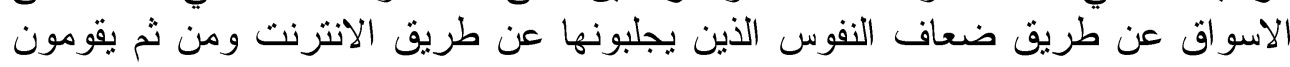

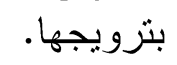

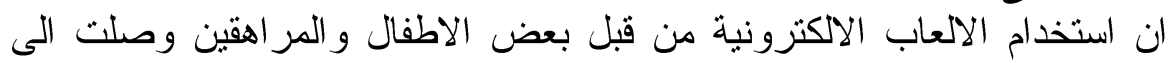

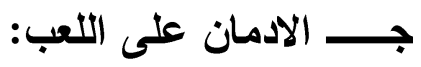

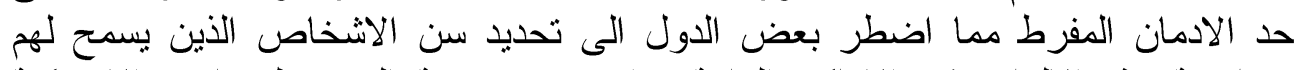

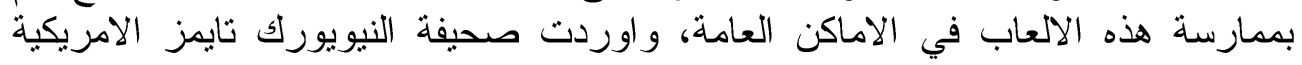

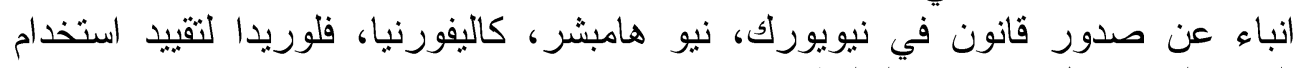
العاب الفيديو نظر الاثار ها ألسلبية.

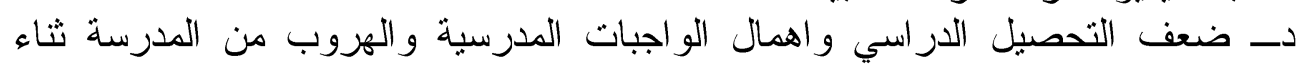

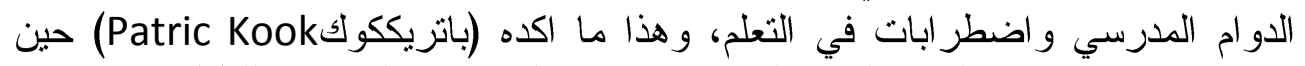

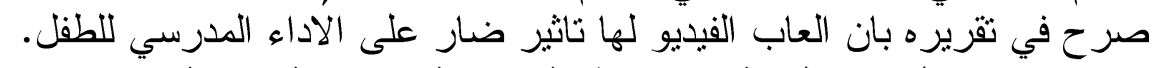

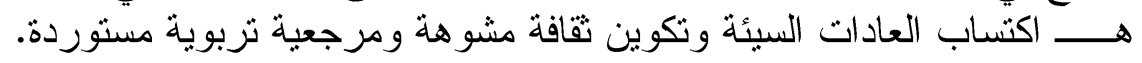

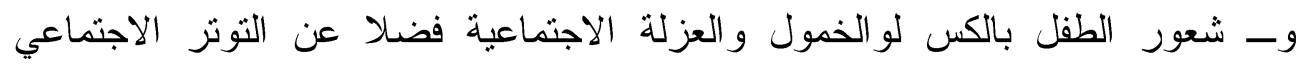

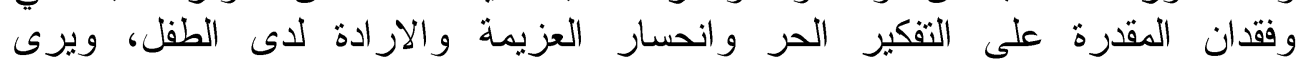

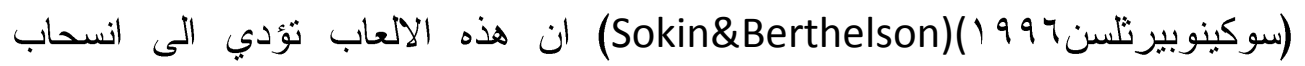

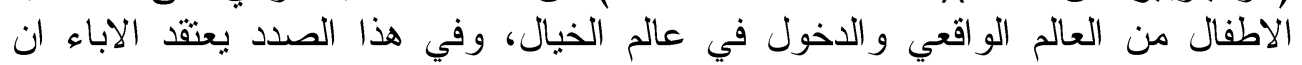

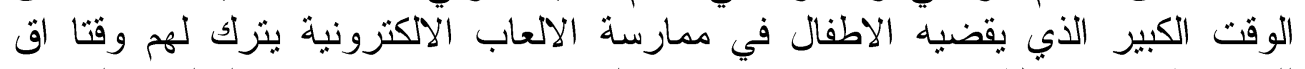

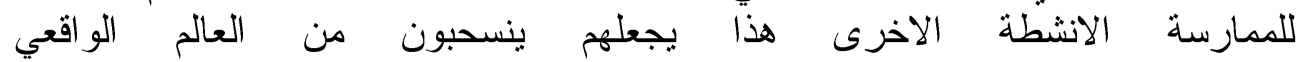

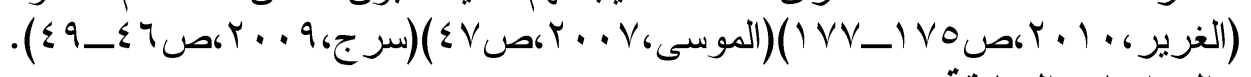

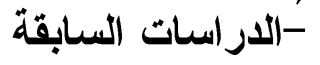

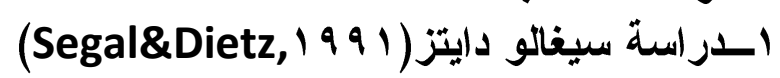

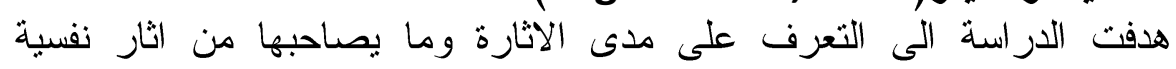

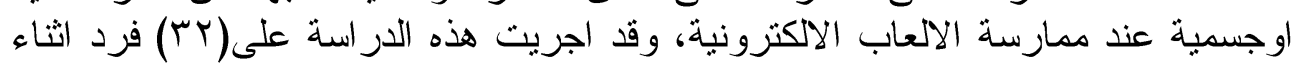

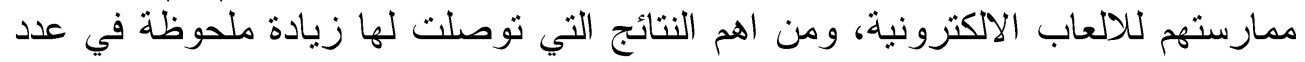

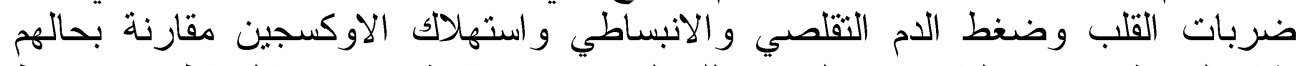

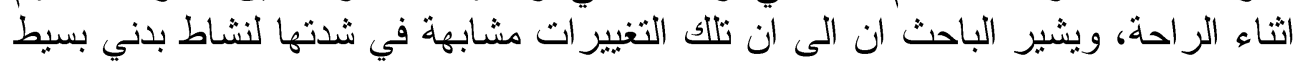

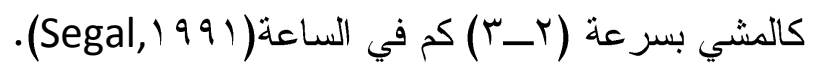




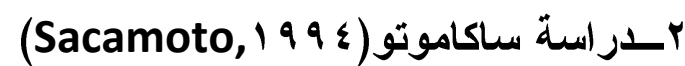

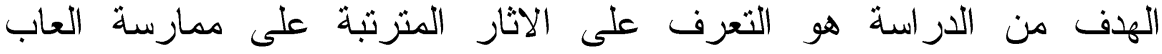

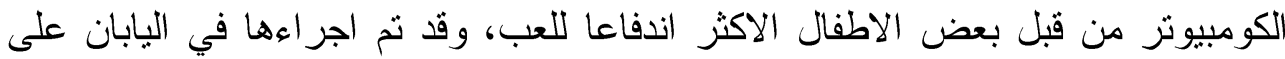

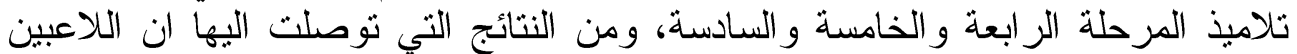
الاكثر اندفاعا الى اللعب يتمتعون بتعاطف اقلى والعة وان هذه الالعاب تعمل على الغاء نشاط

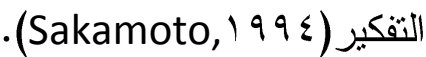

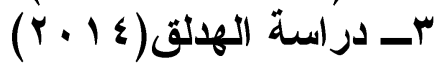

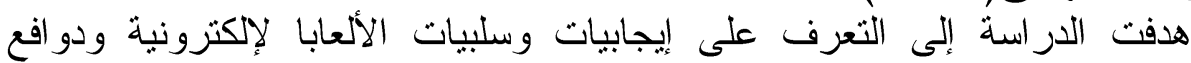
ممارستها من وجهة نظر طلاب التعليم العام بمدينة الرياض. لاض.

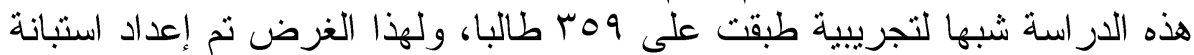

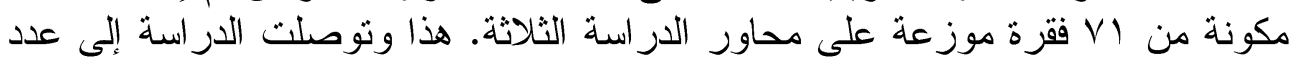

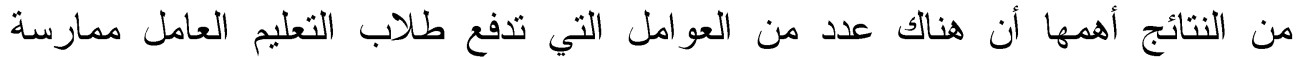

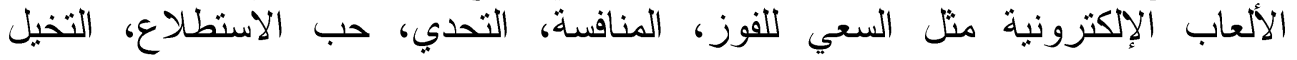

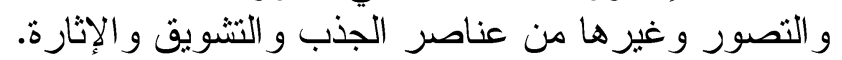

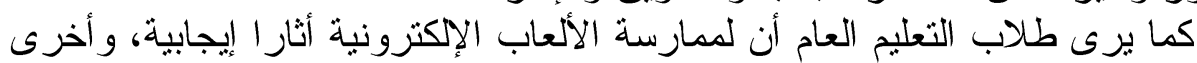
سلبية.

Online فمن الأثار الايجابية أن الألعاب الإلكترونبة التي تمارس عبر الإنترنت games

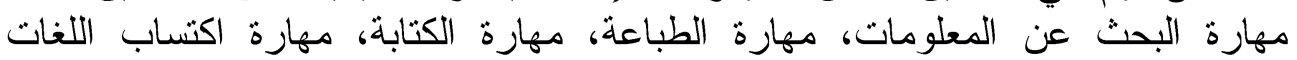

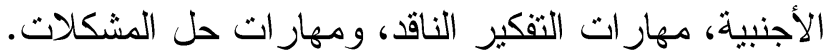

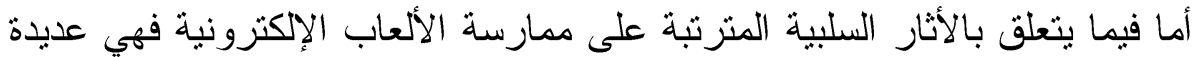

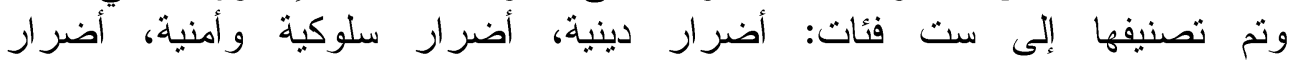

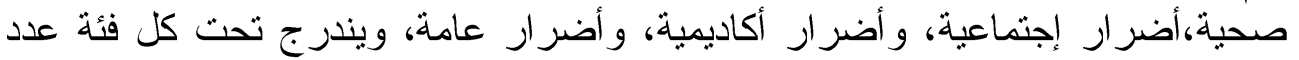

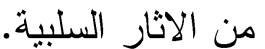

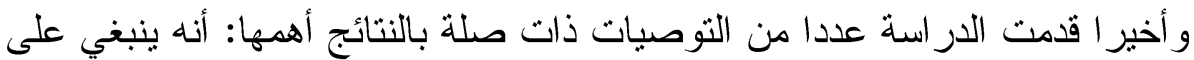

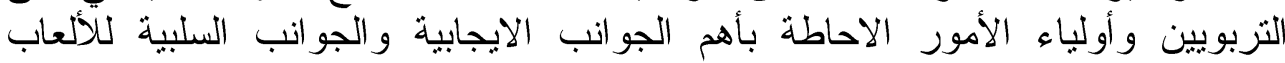

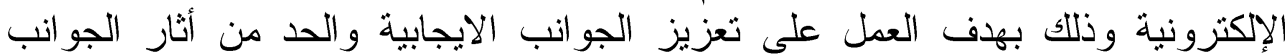

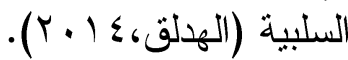

تهدف هذه الدراسة إلى معرفة دور الألعاب الإلكترونية في تعزيز التعددية

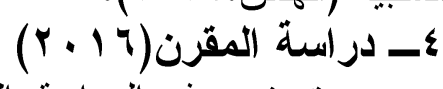

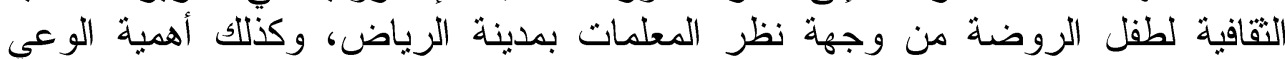

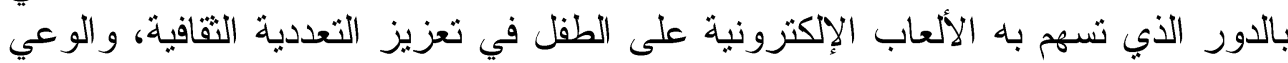

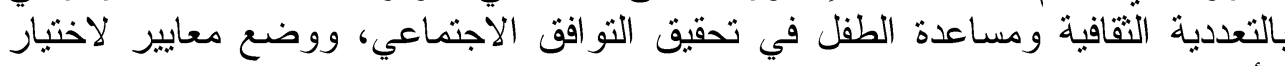
الألعاب الإلكترونية التي تعزية التعدة التعددية التقافية.

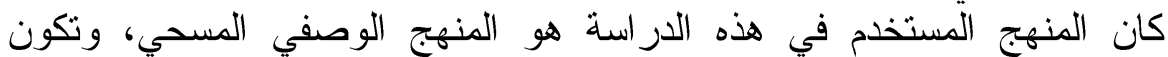

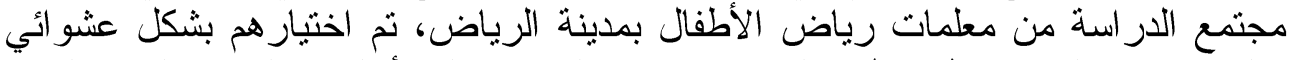

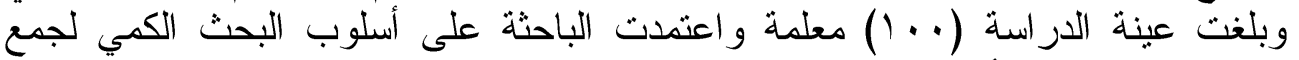

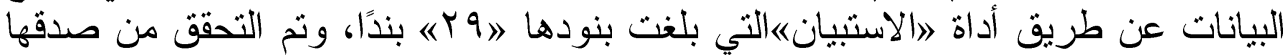

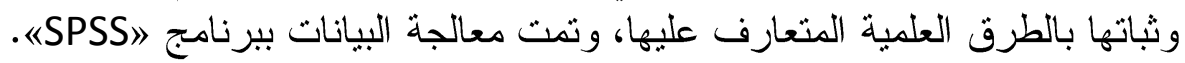




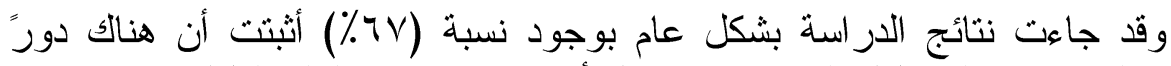

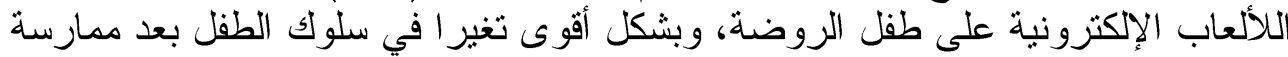

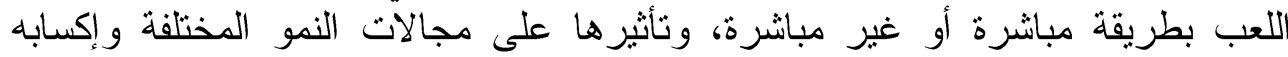

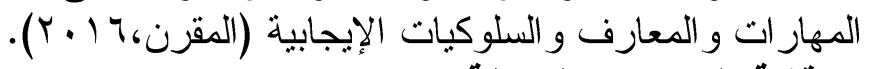

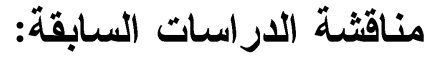

تنفق الدراسات الاربعة مع الدراسة الحالية من حيث المجال، فجميعها تتحدور

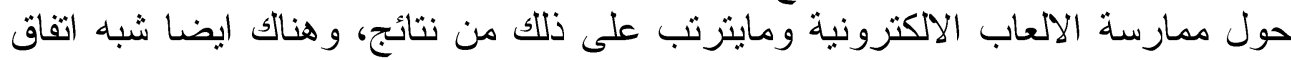

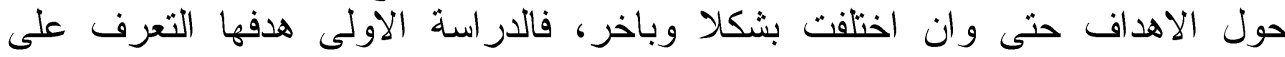

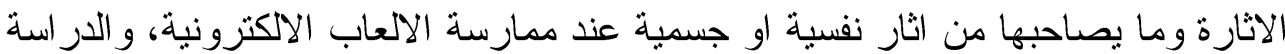

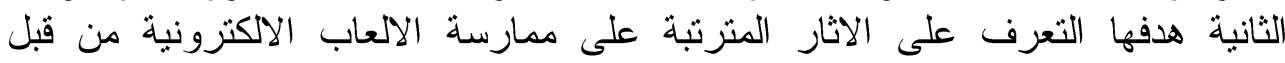

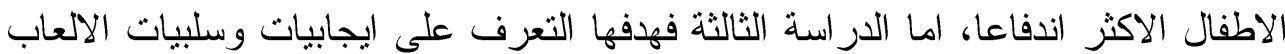

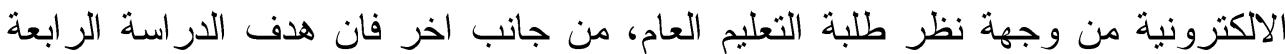

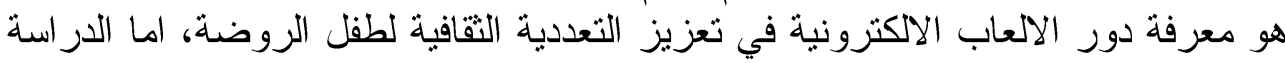

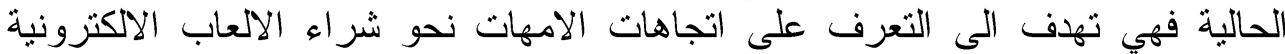

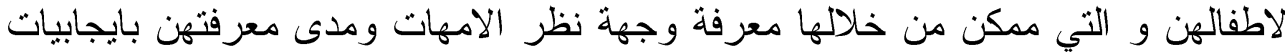
وسلبيات الالعاب الاكترونية.

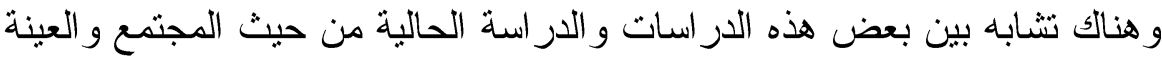

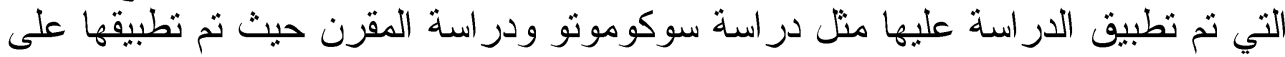

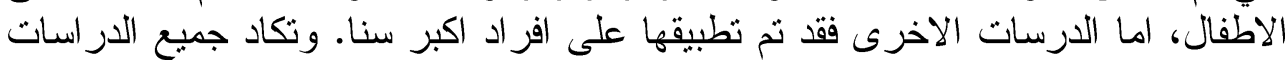

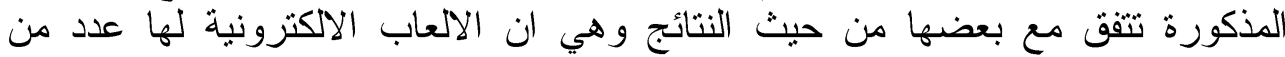

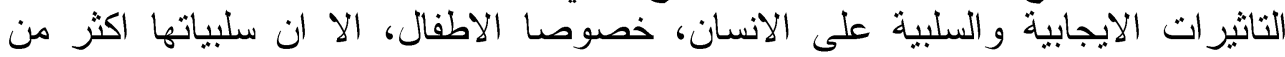

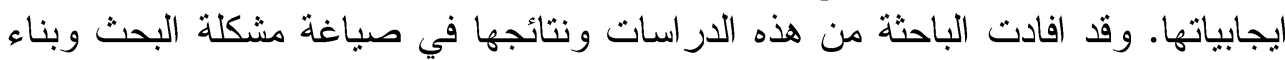

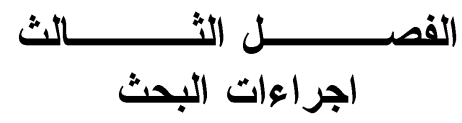

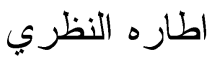

$$
\text { اجراءات البحث البه }
$$

منهجية البحث:للكشف عن اتجاهات الامهات نحو شراء الاء الألعاب الالكترونية لاطفالهن،

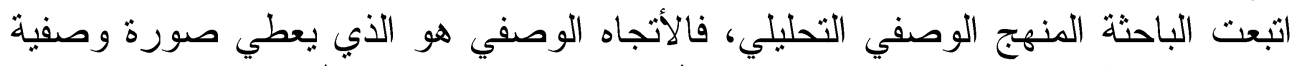

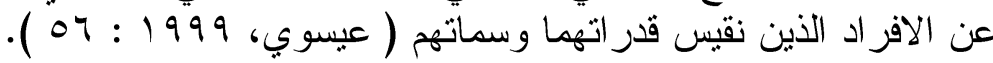

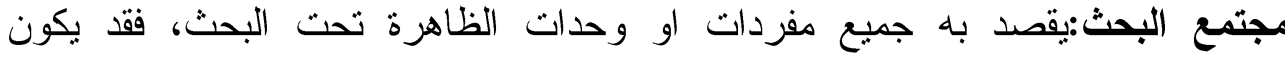

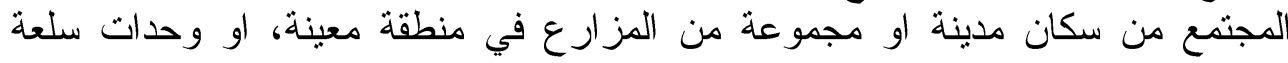

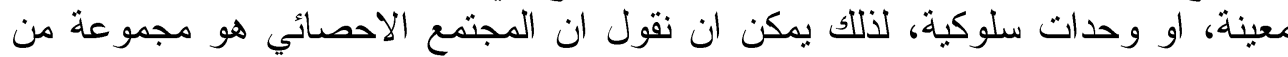

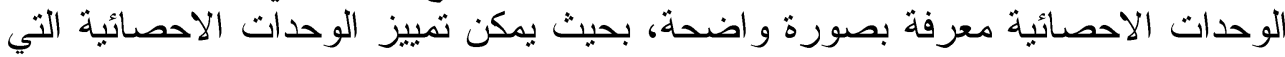

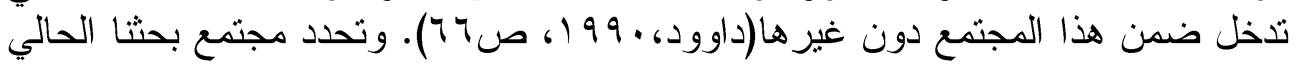

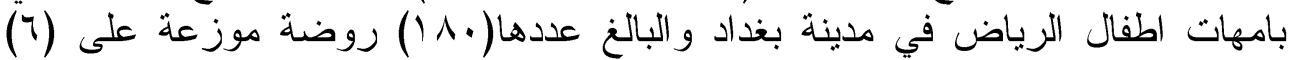

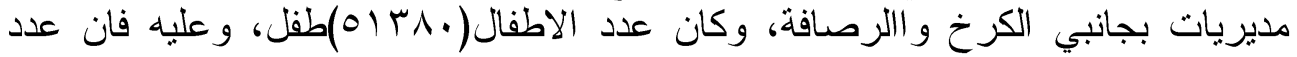

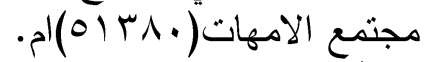

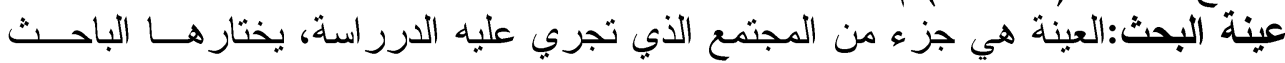

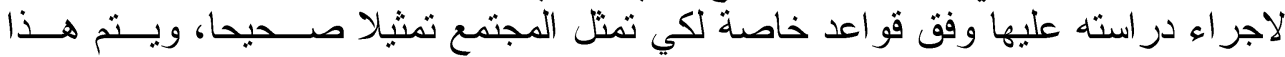

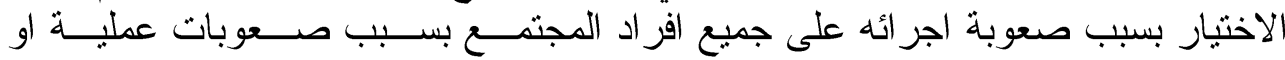

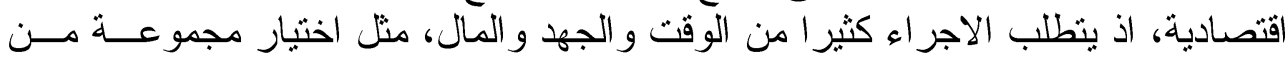




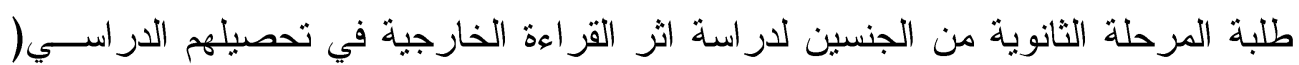

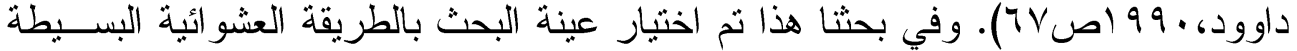
وبتباع الخطو ات الاتية:

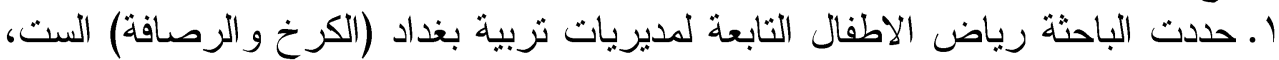

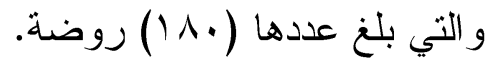

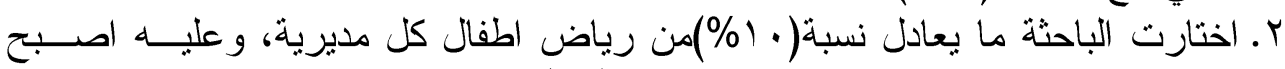

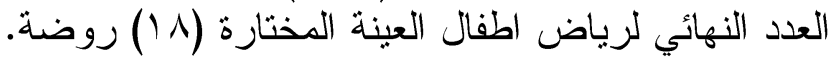

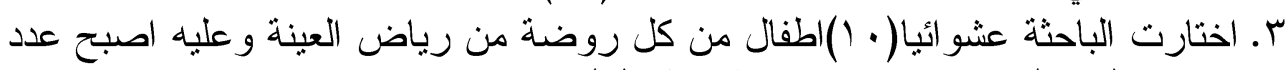

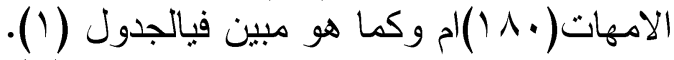

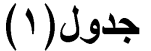

توزيع افراد عينة البحث حسب الرياض

\begin{tabular}{|c|c|c|c|c|}
\hline عدد الامهات & عدد الاطفال & $\%$ & عدد الرياض & المديريـة \\
\hline$r$. & $r$. & $r$ & $r$. & الكرخ الاولى \\
\hline$r$. & $r$. & $r$ & $r$. & الكرخ الثانية \\
\hline$r$. & $r$. & $r$ & IV & الكر خ الثالثة \\
\hline$r$ & $r$. & $r$ & TV & الرصافة الاولى \\
\hline 0. & 0. & 0 & $\varepsilon 9$ & الرصافة الثانية \\
\hline$r$. & $r$. & $r$ & 10 & الرصافة الثالثة \\
\hline 11. & 11. & 11 & 11. & المجمو ع \\
\hline
\end{tabular}

وتبعا للمهنة و التحصيل الدر اسي تم اختيار عينة البحث كما هو مبين في جدول (Y)

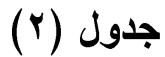

توزيع افر اد عينة البحث حسب التحصيل الدرلمبي واسمهنة

\begin{tabular}{|c|c|c|c|c|}
\hline المجموع & ربة بيت & طالبة & موظفة & التحصيل \\
\hline 9. & 17 & $\varepsilon$ & $V$. & شبكلوريوس عليا \\
\hline or & YI & 1. & rY & دبلوم واعدادي \\
\hline$r v$ & rq & - & $\Lambda$ & متوسط و ابتدائي \\
\hline 11. & 79 & $1 \varepsilon$ & $1 \ldots$ & المجموع \\
\hline
\end{tabular}

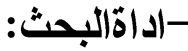

من اجل تعرف اتجاهات امهات الاطفال نحو شر اء الالعاب الالكترونية لاطفــالهن

اعدت الباحثة مقياس البحث باتباع الخطات الخهو ات الات الاتية:

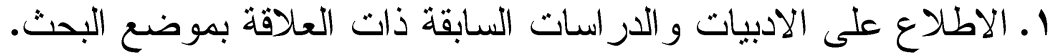

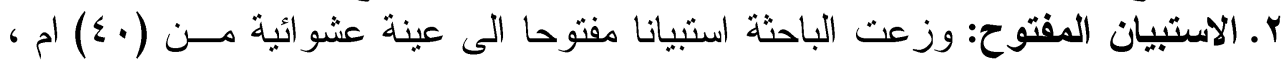

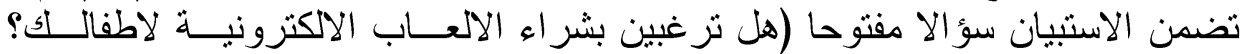

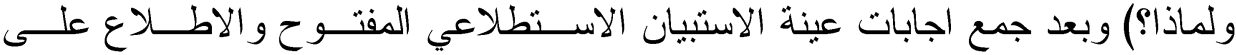

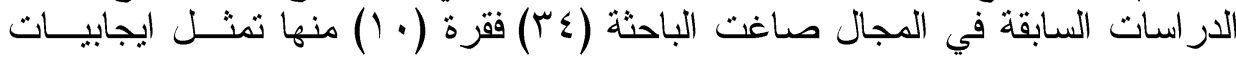

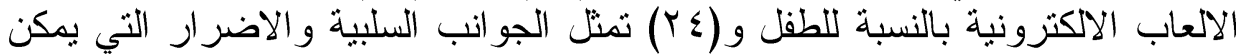




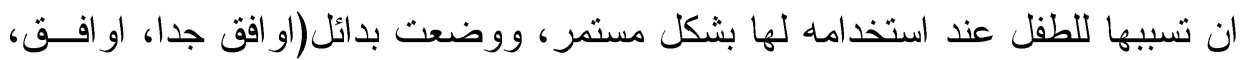

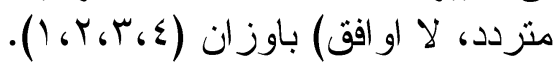
حساب الصدق الظاهري: يعد الصدق من العو امل الاساسية لمستخدم الاختبار او و واضــــهـ

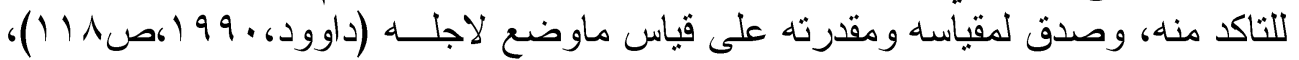

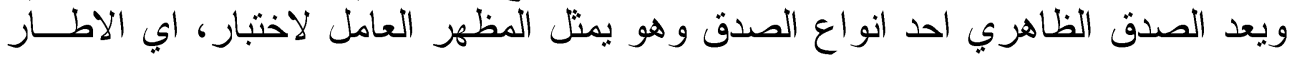

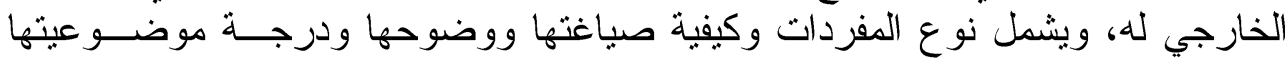

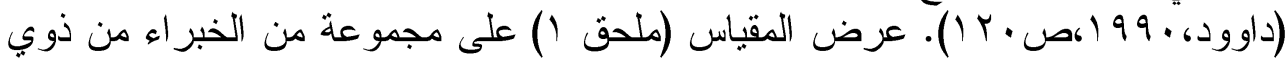
الاختصاص في رياض الاطفال(ملحق ب) للتحقق من صدق فقر ات المقياس، وقد نم الاتفاق

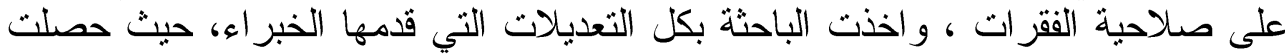

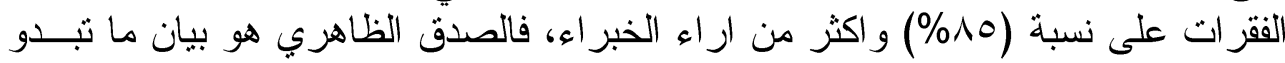

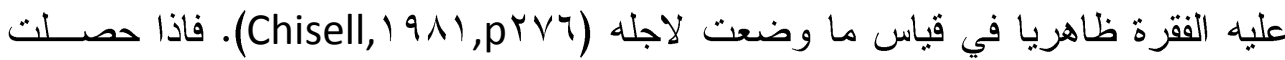

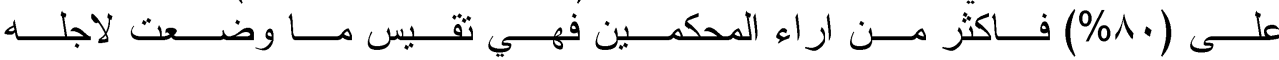

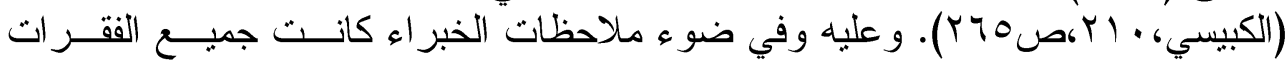

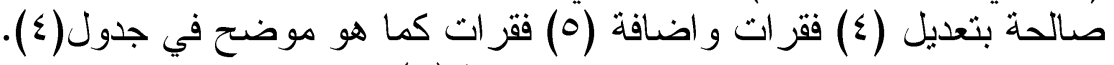

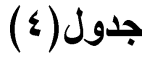

فقرات المقياس قبل التعديل وبعد التعديل والاضافة

\begin{tabular}{|c|c|c|}
\hline الفقر ات بعد التعديل والفقرات المضافة & الفقرات قبل التعديل & $ت$ \\
\hline تؤدي الى ادمان الطفل على استخدامها & قد تؤدي الى ادمان الطفل على استخدامها & 17 \\
\hline تتمي القدرة على التفريق بين الاشياء & يمكن للعبة ان تتمي قدرة الطفل على التفريق & 11 \\
\hline تؤدي الى تعلم الطفل بعض مبادئ & يكن ان يكون للعبة دور في تعلم الطفل بعض الرياض & $r$. \\
\hline تعمل على تدني مستو الإنتماعية على ممارسة & يمكن ان تؤثر بشكل سلبي على مستوى الطفل & $Y \leqslant$ \\
\hline تجعل الطفل عصبي المزاج & & $r$. \\
\hline تسبب الدو ار و الغثيان للطفل & & $r$ \\
\hline تيؤدي الى احمر ار العينين & & ru \\
\hline تسبب الصداع & & r \\
\hline تجعل الطفل عنيف & & ए๘ \\
\hline
\end{tabular}

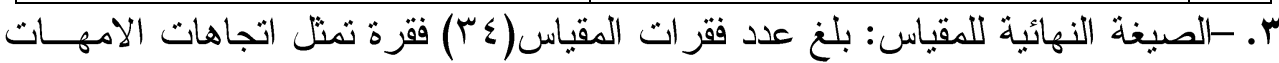

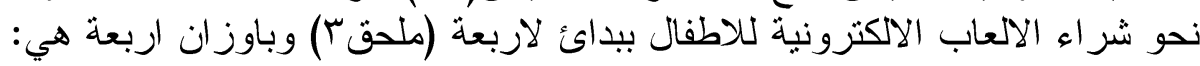

$$
\begin{aligned}
& \text { ــ اوافق جدا تحصل على(ع) درجات. }
\end{aligned}
$$

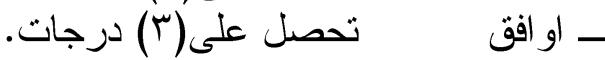

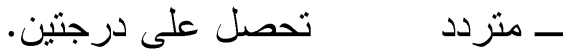

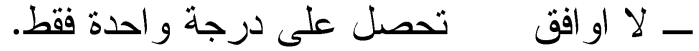

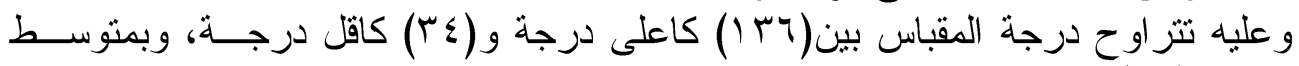

$$
\text { فرضي(10)درجة. }
$$

ع. -التطبيق النهائي: وزعت الباحثة المقباس بصيغته النهائية على عبنـة البحث المكونـــة

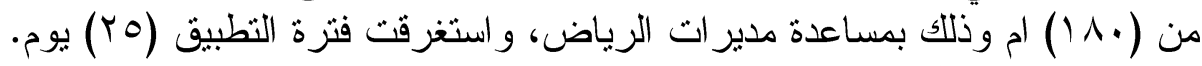

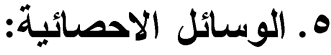

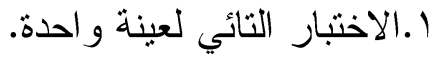
r. با.حليل الثباين الاحادي. 


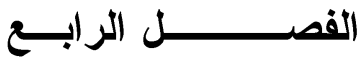 \\ نتائج البحث ومناقشتها}

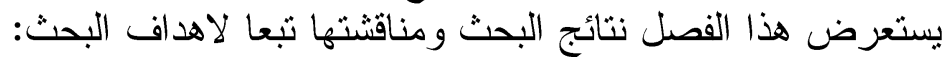

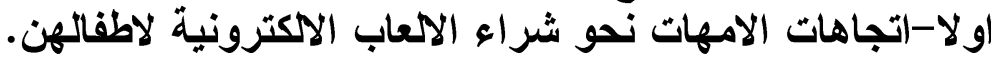

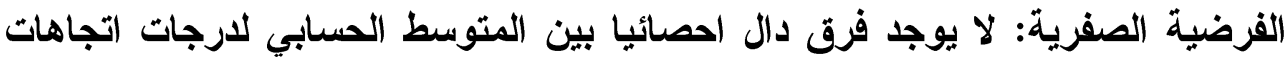

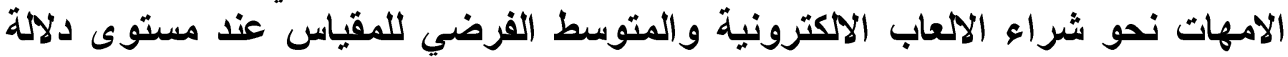

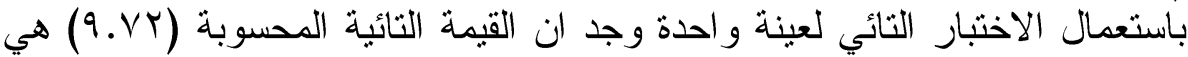

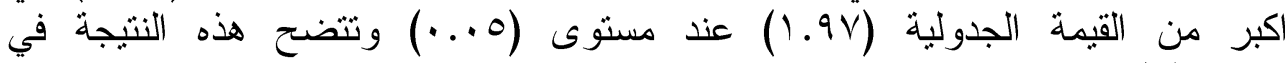

$$
\text { جدول ( ) }
$$

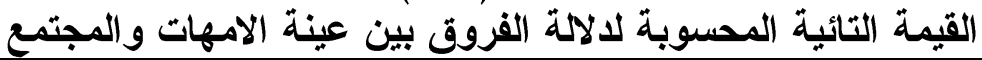

\begin{tabular}{|c|c|c|c|c|}
\hline القيمة التائية & الوسط الفرضي & الانحرياري & الوسط الحسابي & العينة \\
\hline $9 . V Y$ & 10 & Ir.V. & $V O . V V$ & 11. \\
\hline
\end{tabular}

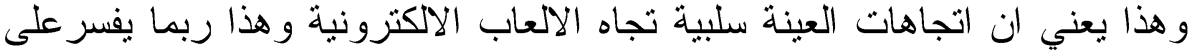

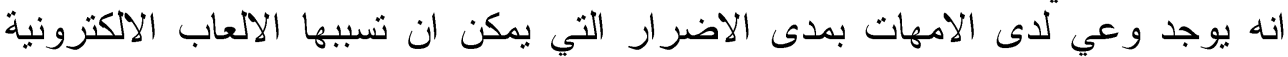

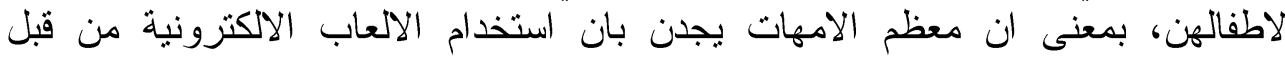

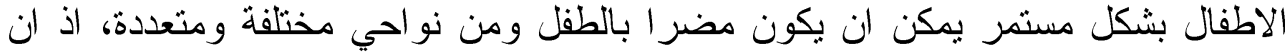

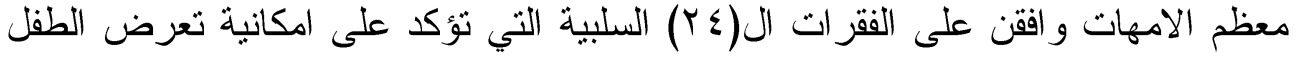

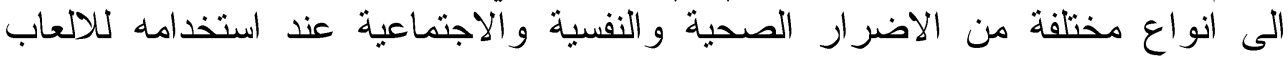

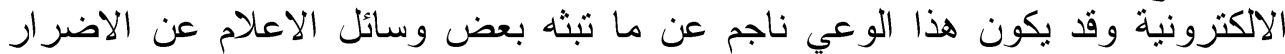

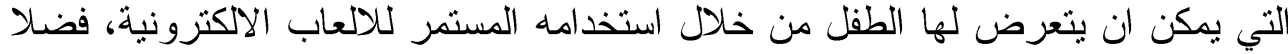

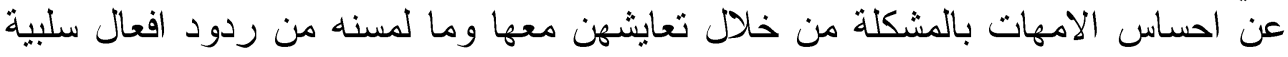
و مشاكل صحية ونفسية واجتماعية عانى منها اطفالهن من خلال استخدامهم المستمر لهذال

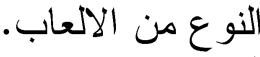

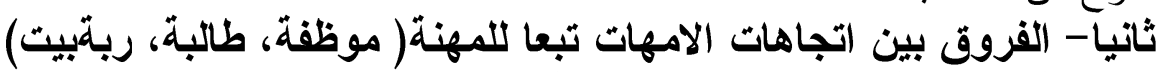

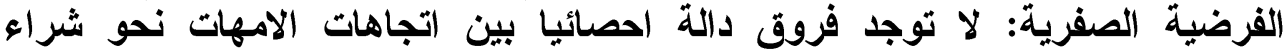

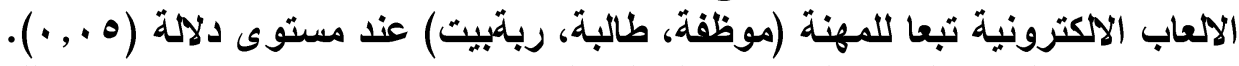

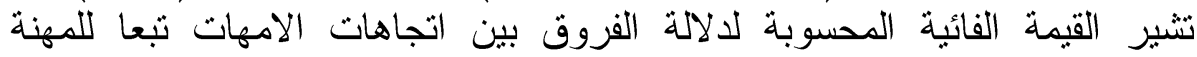

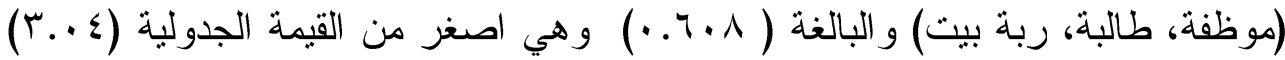

$$
\text { عندمستوى (0. . .) وكما مبين في الجدول ( جدول (7 ) ). }
$$

\begin{tabular}{|c|c|c|c|c|}
\hline القيمسوبة الفائية & متوسط المربعات & درجة الحرية & المربعات & التباين \\
\hline \multirow{3}{*}{$.7 \cdot 1$} & $1 . \varepsilon . V 11$ & $r$ & Y.q.\&Y & بين المجموعات \\
\hline & IVY.YIY & IVV & $r . \leqslant \wedge 1 . \leqslant V_{0}$ & ضمن المجموعات \\
\hline & & 189 & $5.79 . .911$ & المجموع \\
\hline
\end{tabular}

القيمة الفائية المحسوبة لالالة الفروق بين الاتجاهات تبعا لمهنة الام 
و هذا يعني ان لا فروق بين الامهات سو اء اكانت موظفة ام طالبة ام ربة بيت، وقاء

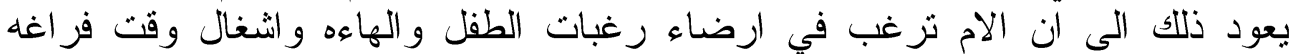

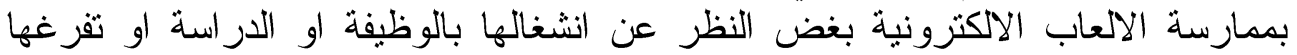

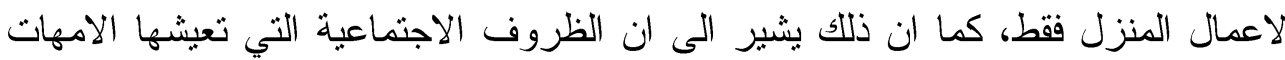

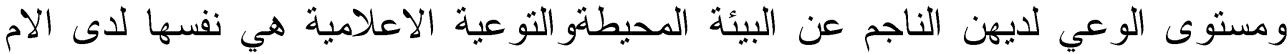

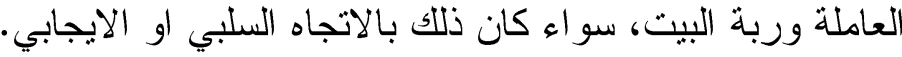

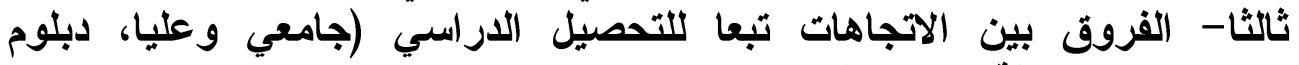

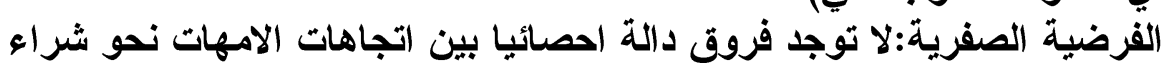
واعدادي، متوسطة وابتدائي)

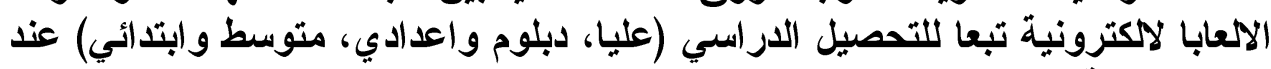
مستوى دلامة (0 + , • ).

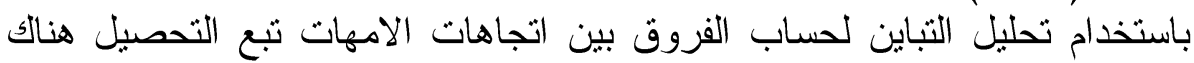

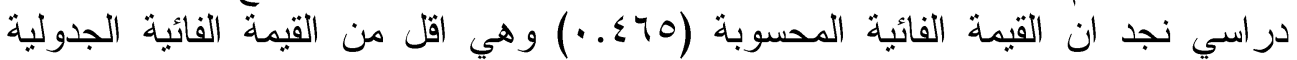

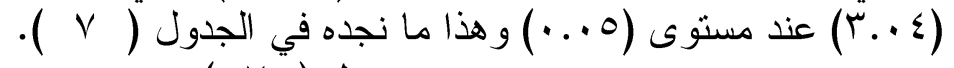

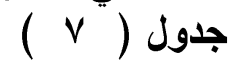

القيمة الفائية المحسوبة لالالة الفروق بين الاتجاهات تبعا لتحصيل الام الدراسي

\begin{tabular}{|c|c|c|c|c|}
\hline القيمسة الفائية & متوسط المربعات & درجة الحرية & المربعات & التباين \\
\hline \multirow{3}{*}{.$\leqslant 40$} & VY.1.1 & $r$ & $1 \leq \varepsilon . Y \cdot Y$ & بين المجموعات \\
\hline & $100 . .79$ & IVV & $r V \leqslant \varepsilon V .19 T$ & ضمن المجموعات \\
\hline & & 189 & $r v \Delta q 1 . r q \varepsilon$ & المجموع \\
\hline
\end{tabular}

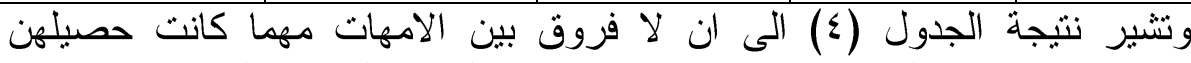

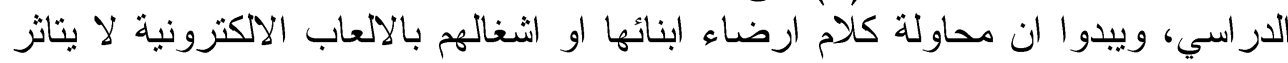

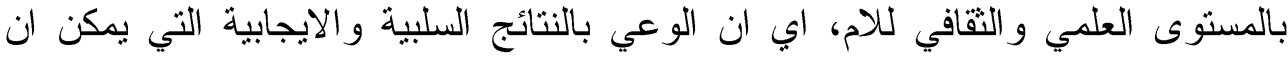

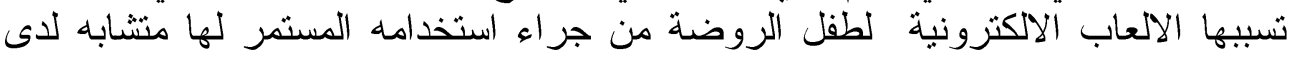

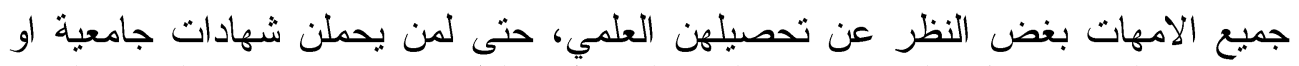

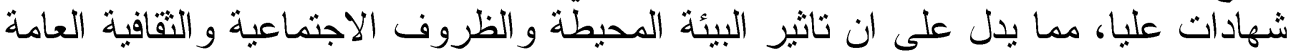

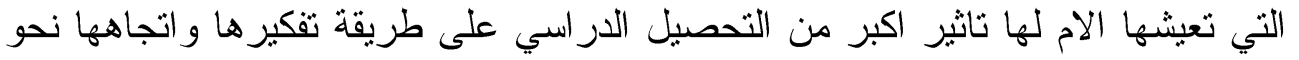

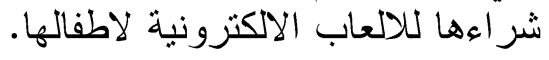

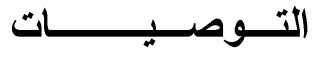

بناء| على ما تقدم توصي الباحثة بما يلي:

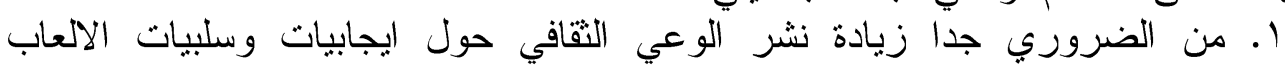

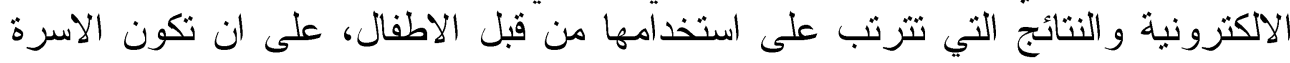

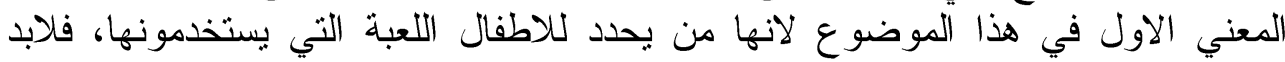

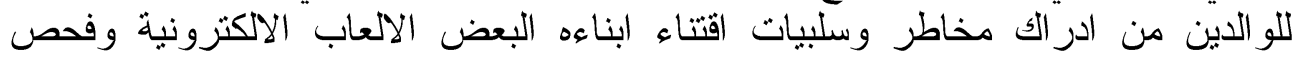

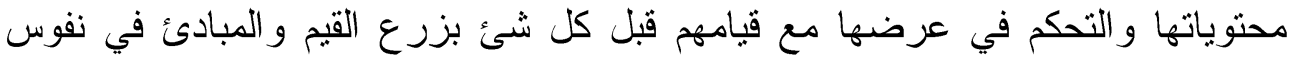

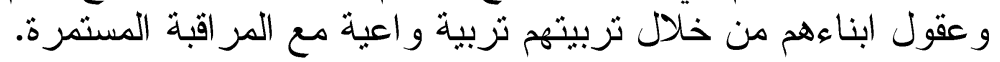

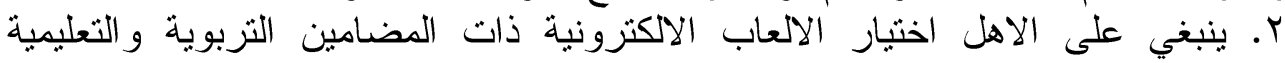

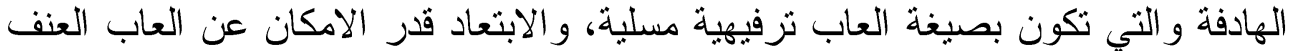

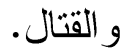




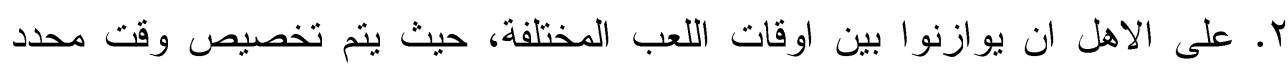

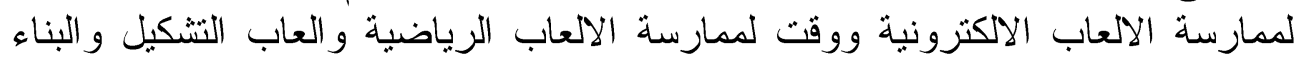

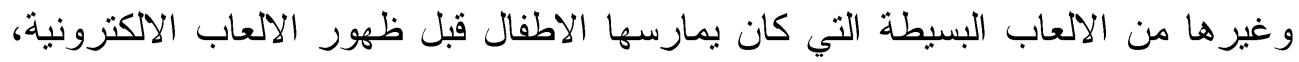

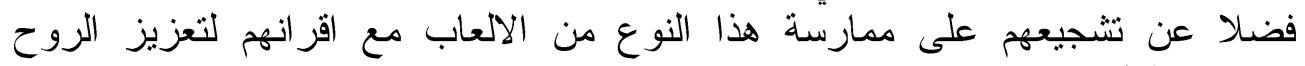

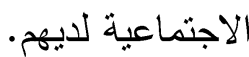
ب. هنالك اوقات ينبغي لائه على الو الدين أن لا يسمح الطفل بممارسة الألعاب الإلكترونية فيها،

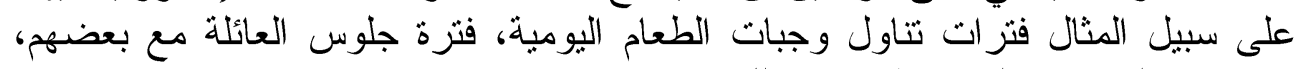

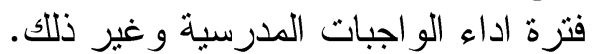

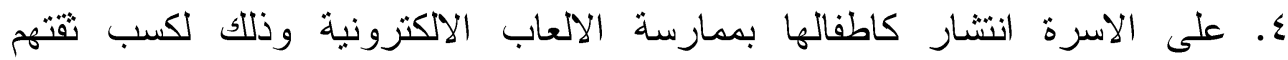

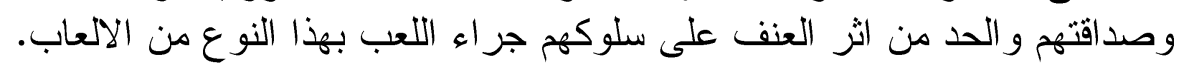

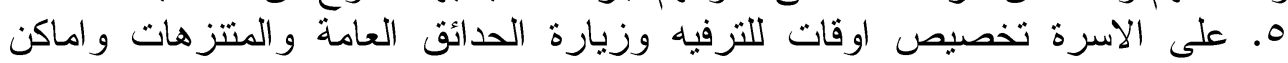

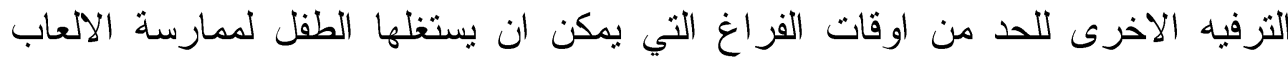

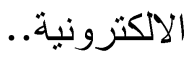
المقترحات المترونة

ا.اجز اء بحوث تجريبة ميدانية حول بعض الامر اض الصحية التي يمكن ان يتعرض لها

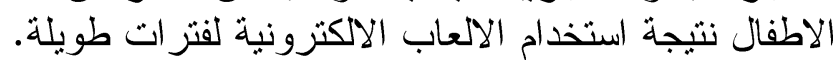

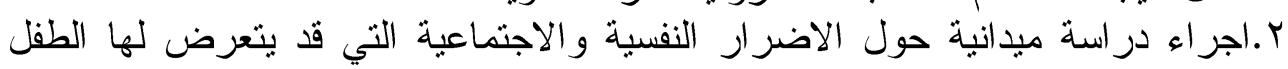
نتيجة الاستخدام المستمر للإلعاب. r.اجر اء در اسة ميدانية حول المكانية استخدام الالعاب الالكترونية لتحقيق بعض الاهداف التربوية او التعليمبة. 


\section{Abstract \\ Mothers' attitudes towards buying electronic toys for their children \\ By shimaa harith muhamad}

The research aims to identify the trends of mothers towards the purchase of the electronic games for their children, and if the mother was a career and collected scientific have an impact on this trend, and to achieve the goals of research, the researcher building closed questionnaire adopted in the construction on the literature and previous studies in the field of research, as well as an open questionnaire distributed to prospective sample of mothers have been through direct two questions have two: Do you prefer to buy electronic games for your children? And why? Through their answers analysis managed researcher to identify the paragraphs of the closed questionnaire, namely, $(\Gamma \varepsilon)$, paragraph turns out the pros and cons of electronic games for children and alternatives (I agree too, I agree, AC,I don't agree), and these forms are distributed to a random sample of mothers, children, the city of Baghdad, which range from the ages of $\Sigma_{-} \uparrow$ years numbered $1 \wedge$. or dependent distribution of the variables of the profession and academic achievement, and after collecting the forms and discharged and extract the number of iterations and the use of the test Altai for one sample and analysis of variance unilateral means statistically, was reached a set of conclusions, including that mothers trends some buy electronic games a negative meaning that most mothers find that the electronic games can cause different damage to their babies if they were used on an ongoing basis. the results also showed that not a profession and educational attainment no effect on maternal attitudes towards the purchase of the electronic games for their children, which shows that mothers thinking in this area because of similar because they are living under the same conditions and the same type of culture in this area.

Based on results research was presented a number of recommendations concerning the need to take care of public culture and correct guidance in the field of electronic games and get to know the negatives and positives to be the direction of parents' right and conscious when purchasing electronic games for their children.

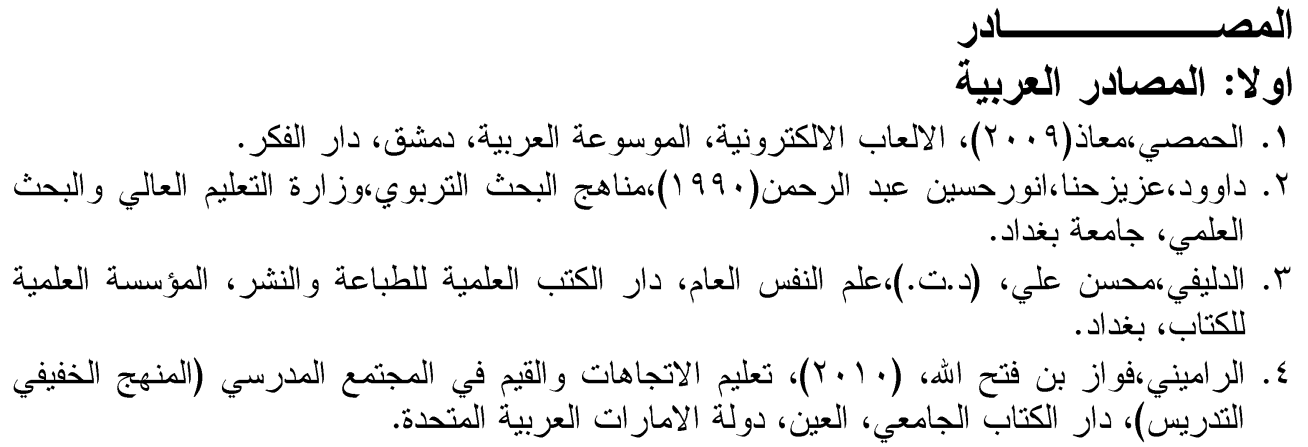




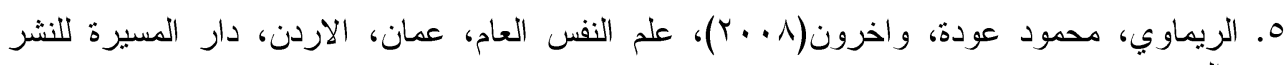

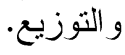

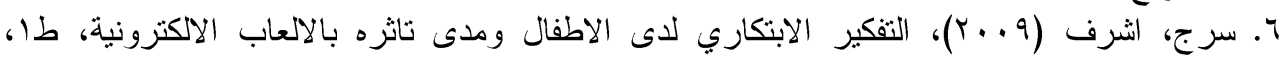

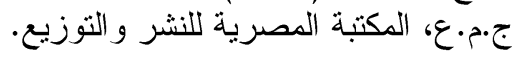

V. عبسوي، عبد الرحمن محمد ( 1999 (1992) : القياس والتجريب في علم النفس والتربية، دار المعرفة

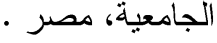

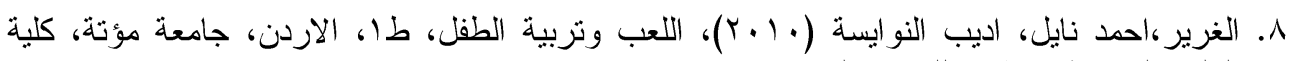

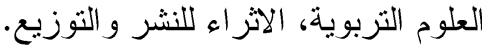

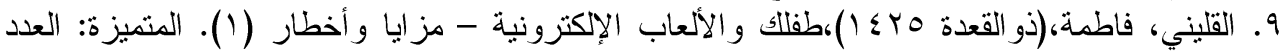

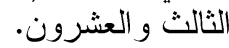

• 1. الكامل، محمود(9 . . r)، الالعاب التربوية استر اتيجية لتتمية التفكير، حلب، جامعة حلب، مجلة كلية الهندسة.

ال. محمد، عادل عبداله(1999 ()، دراسات في نمو طفل الروضة، عمان، دار الرشد للطباعة و النشر

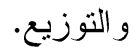

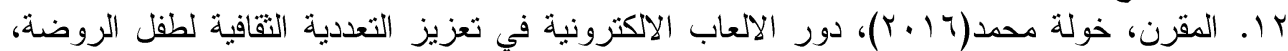

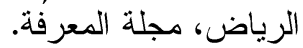

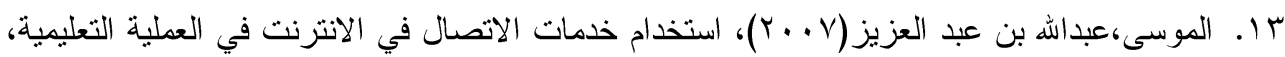
جامعة محمد بن سعود الاسلامية.

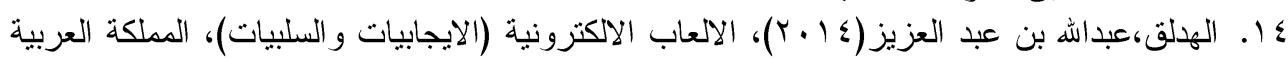

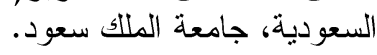

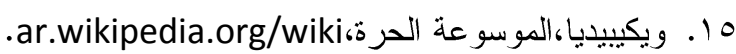

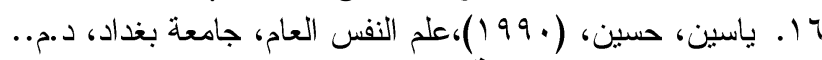
ثانيا: المصادر الاجنبية

1. Gunter,B.(199^), The effects of video games on children, The myth unmasked Sheffield, UK, Sheffield Academic press.

r. Sacamoto,A.( ( 99 §), Vidio game use and the development of socio cognitive abilities in children, three surges of elementary school children.

r. Sigal,K. \& Dietz W.( (१९)), Phsycologic responses to playing a video game, AM., JDIS child. 


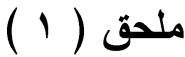

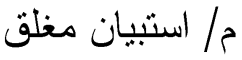

جامعة بغداد كلية التزبية للبنات الإن

قسم رياض الاطفال

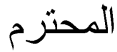

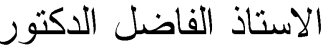
تحية طيبة تروم الباحثة اجر اء دراسة حول اتجاهات الامهات نحو شر اء الالعاب الالكترونية

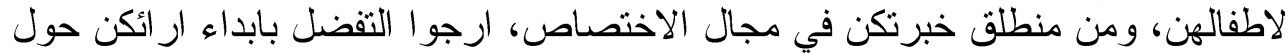
مدى صلاحية فقر ات الاستبيان. علما ان البدائل هي: او افق جدا، او الفق ، متردد ، لا او افق الباحثة مع فائق الثكر و الثقدير لات

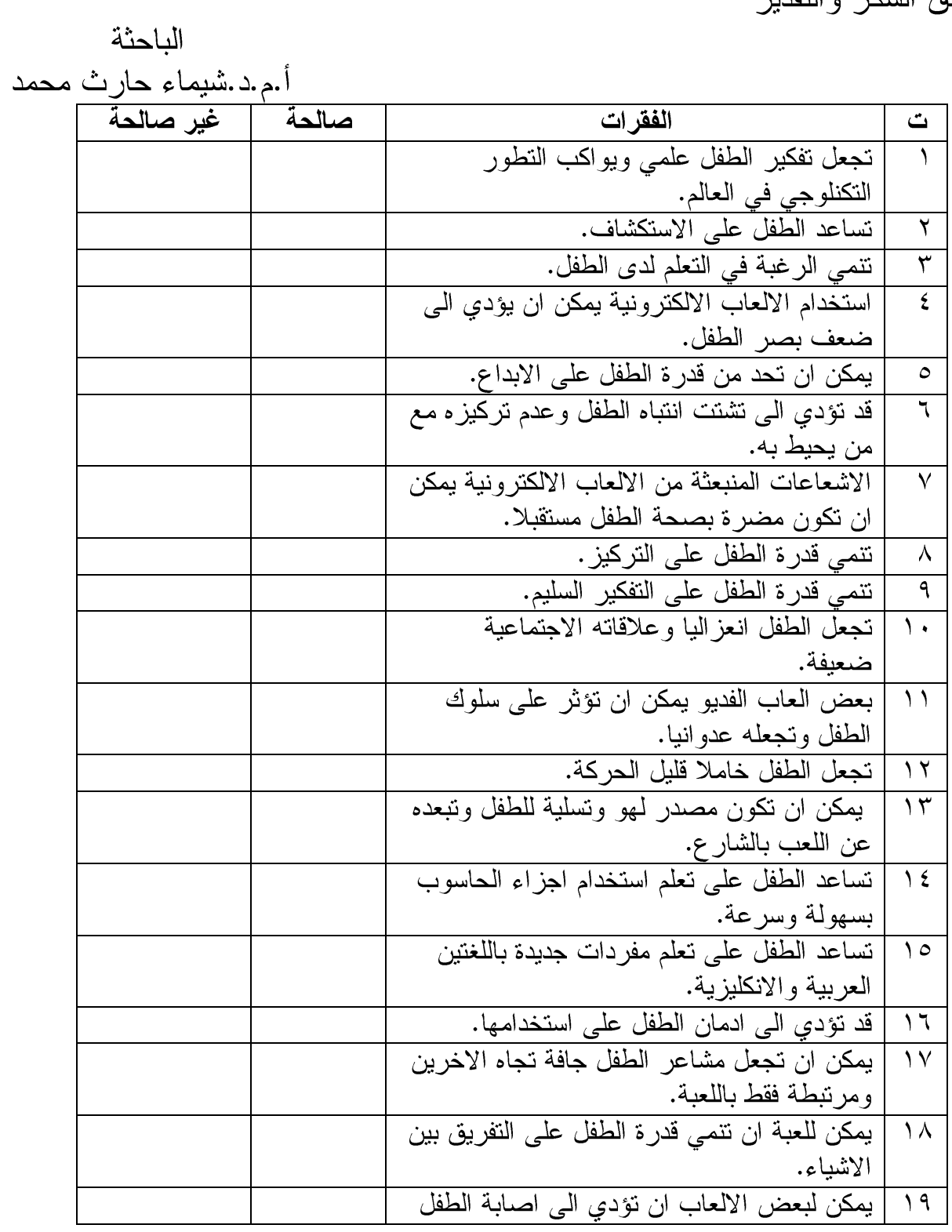




\begin{tabular}{|c|c|c|c|}
\hline & & بالاحباطة اذاذ كانت اعلى من مستو ق قدر اته & \\
\hline & & الرباضنبات يكون للعبة دور في تعلم بعض مبادئ & $r$. \\
\hline & & 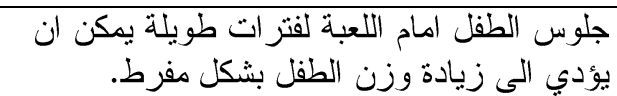 & $r_{1}$ \\
\hline & & 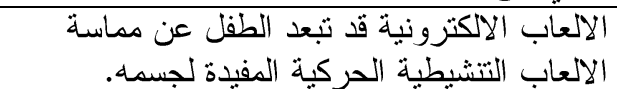 & TrY \\
\hline & & 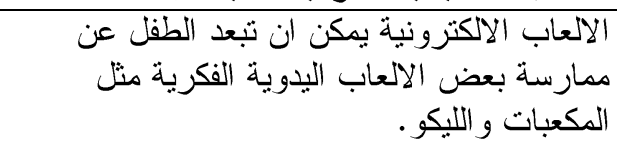 & $r r$ \\
\hline & & النتعليمن ان تؤثر بشكل سلبي على مستوى الطفل & $r \varepsilon$ \\
\hline & & 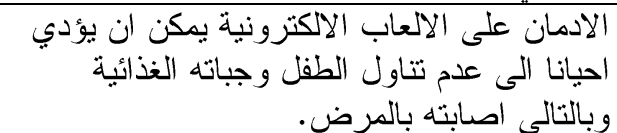 & ro \\
\hline & & 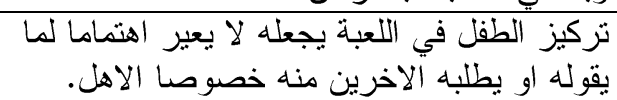 & YY \\
\hline & & 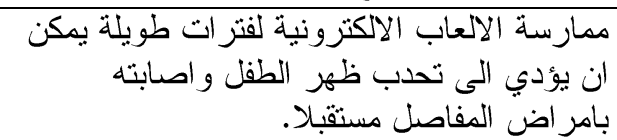 & $r V$ \\
\hline & & قادر على تقلير قلى الالعاب الألكترونية يجعله غير & rA \\
\hline & & 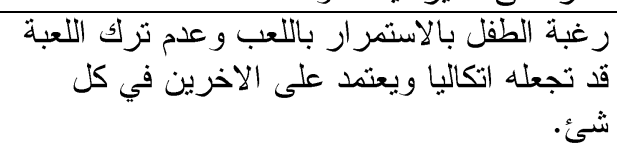 & rq \\
\hline
\end{tabular}




\section{ملحق (r) (r)

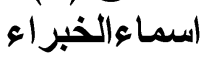

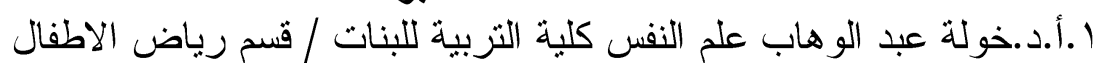

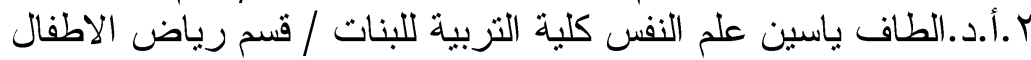

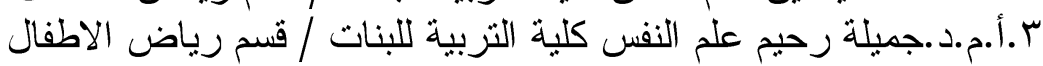

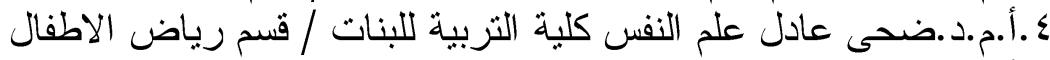

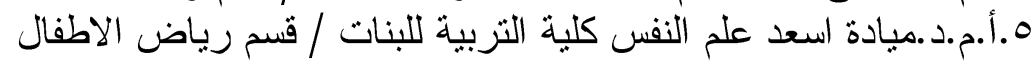

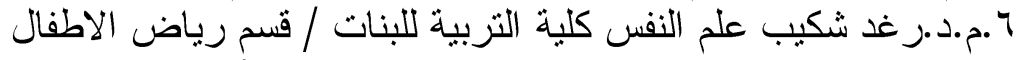

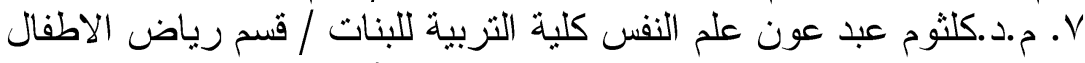

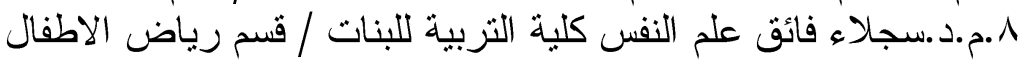

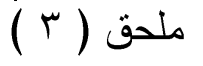

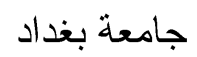
كلية التربية للبنات

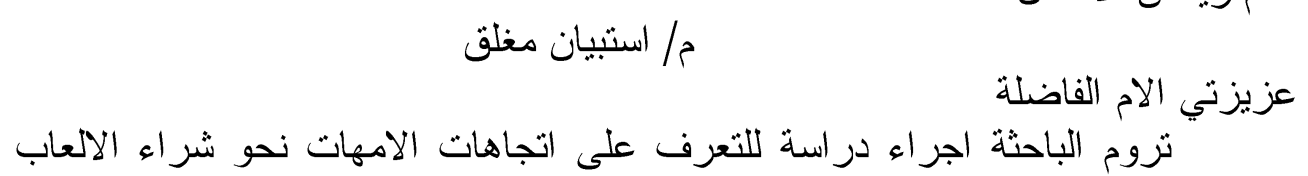
قسم رياض الاطفال

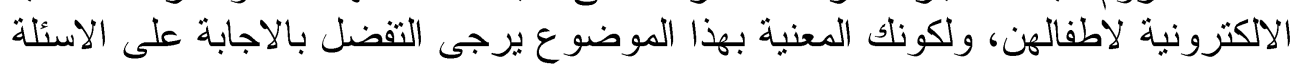

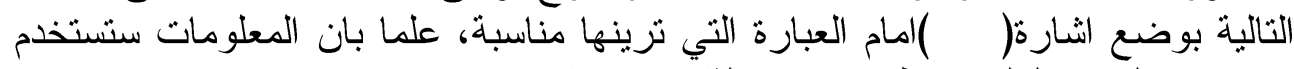

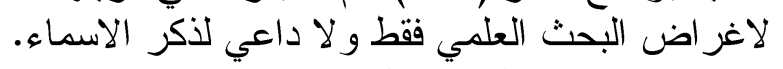
مع فائق الثكر و الثقدير

الباحثة

د. - اليماء حارث محمد

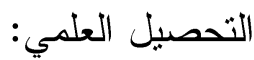

\begin{tabular}{|c|c|c|c|c|c|}
\hline & & e & رباً & ) طالبة ( & المهن \\
\hline لا لاو اوفق & 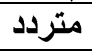 & او افق & 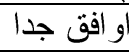 & 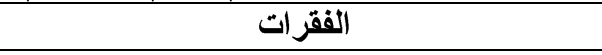 & $ت$ \\
\hline & & & & 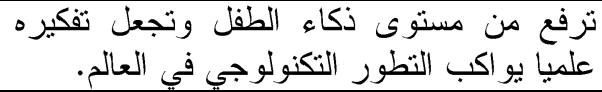 & 1 \\
\hline & & & & تساعد الطفل على الاستكشاف. & r \\
\hline & & & & تتمي الرغبة في التعلم لاى الطفل. & $r$ \\
\hline & & & & استخدام الالعاب الآكترونية يؤدي الى ضعف & $\varepsilon$ \\
\hline & & & & تحد من قدرة الطفل على الابداع. & 0 \\
\hline & & & & من بوديط الى تثتيت انتباه الطفل وعدم تركيزه مع & 7 \\
\hline & & & & 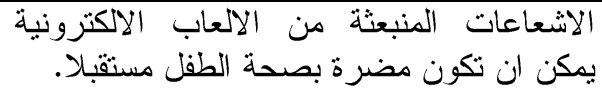 & V \\
\hline & & & & تتمي قدرة الطفل على التزكيز . & $\Lambda$ \\
\hline & & & & تنمي قدرة الطفل على التفكير السليج. & 9 \\
\hline & & & & تُعيفة. الطفل انعز اليا و وعلاقاته الاجتماعية & 1. \\
\hline & & & & الطفل وتجعله عدو النيا. يمكن ان تؤثر على سلوك & 11 \\
\hline
\end{tabular}




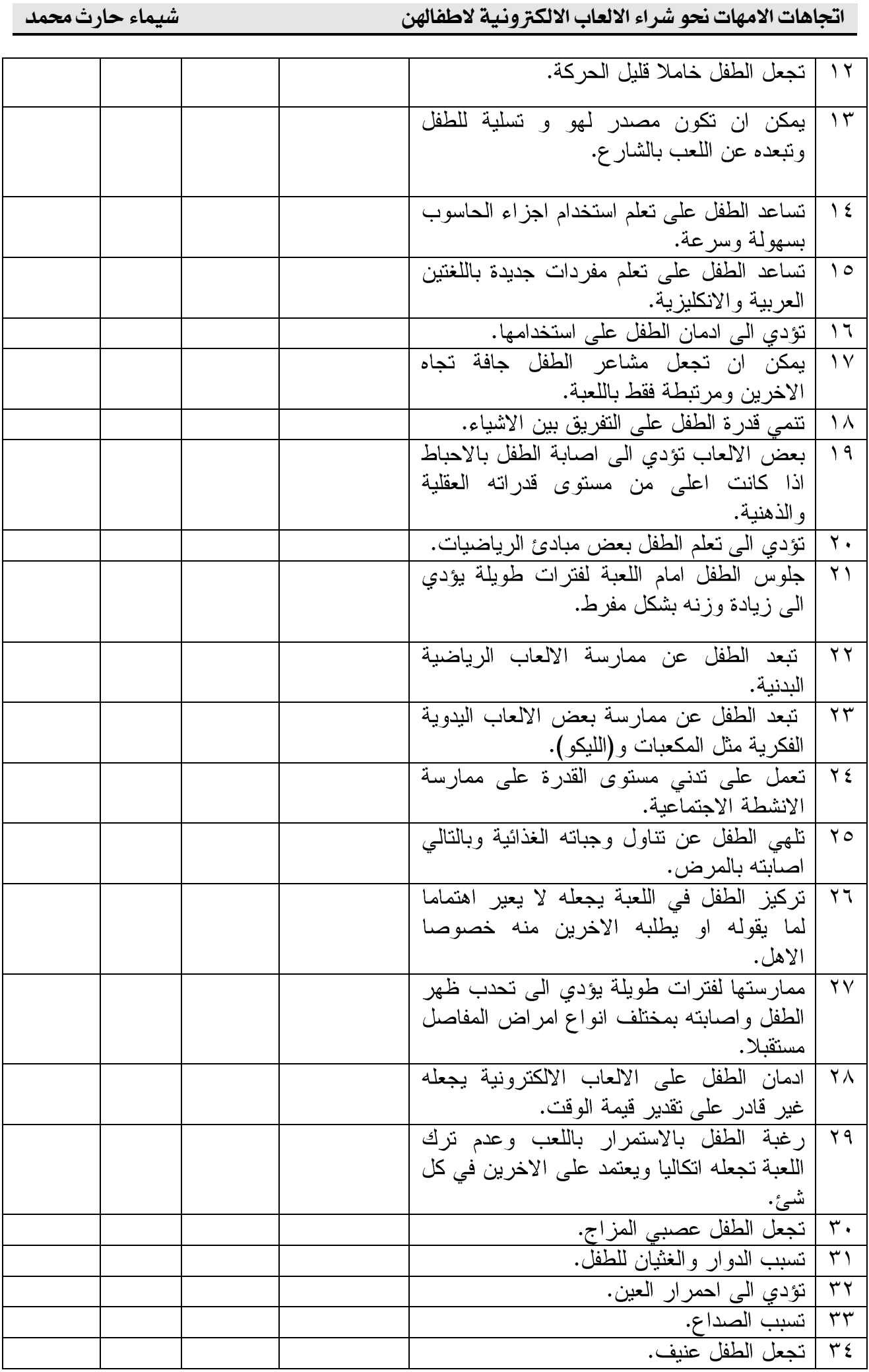

